ESRI

RESEARCH

SERIES

NUMBER 89

June 2019
POLICY AND PRACTICE TARGETING THE LABOUR MARKET INTEGRATION OF NON-EU NATIONALS IN IRELAND

SAMANTHA ARNOLD, EMMA QUINN, SARAH GROARKE, FRAN MCGINNITY AND CHRISTINA DURST

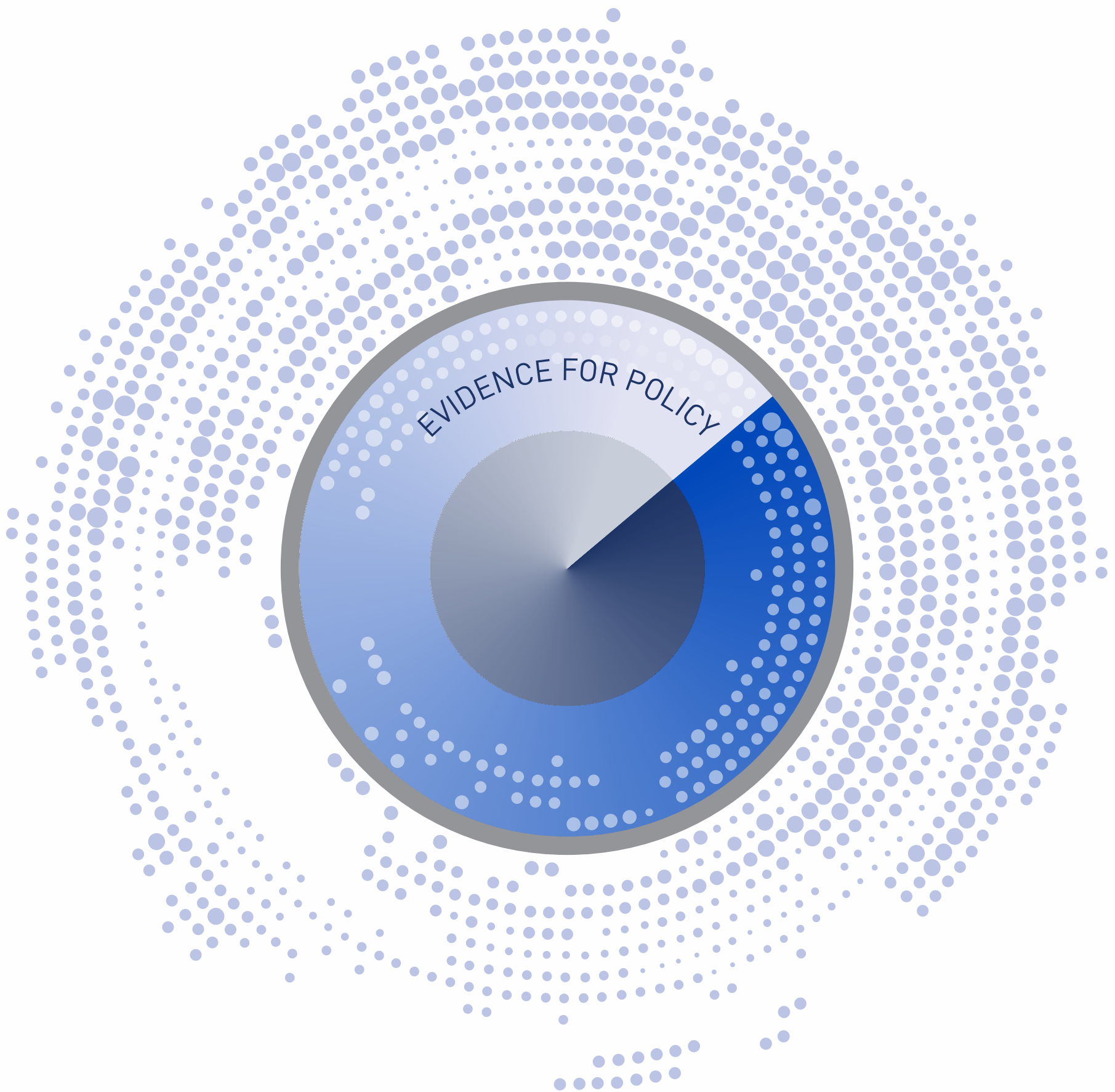





\section{POLICY AND PRACTICE TARGETING THE LABOUR MARKET INTEGRATION OF NON-EU NATIONALS IN IRELAND}

Samantha Arnold

Emma Quinn

Sarah Groarke

Frances McGinnity

Christina Durst

June 2019

\section{RESEARCH SERIES}

\section{NUMBER 89}

Study completed by the Irish National Contact Point of the European Migration Network (EMN), which is financially supported by the European Union and the Irish Department of Justice and Equality. The EMN was established via Council Decision 2008/381/EC.

Available to download from www.emn.ie

(C) The Economic and Social Research Institute

Whitaker Square, Sir John Rogerson's Quay, Dublin 2

ISBN: 978-0-7070-0494-5

DOI: https://doi.org/10.26504/rs89

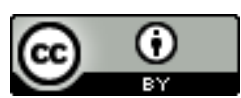

This Open Access work is licensed under a Creative Commons Attribution 4.0 International License, which permits unrestricted use, distribution, and reproduction in any medium, provided the original work is properly credited. 


\section{THE EUROPEAN MIGRATION NETWORK}

The aim of the European Migration Network (EMN) is to provide up-to-date, objective, reliable and comparable information on migration and asylum at Member State and EU levels with a view to supporting policymaking and informing the general public.

The Irish National Contact Point of the European Migration Network, EMN Ireland, sits within the Economic and Social Research Institute (ESRI).

\section{ABOUT THE ESRI}

The mission of the Economic and Social Research Institute is to advance evidencebased policymaking that supports economic sustainability and social progress in Ireland. ESRI researchers apply the highest standards of academic excellence to challenges facing policymakers, focusing on 12 areas of critical importance to 21 st Century Ireland.

The Institute was founded in 1960 by a group of senior civil servants led by Dr T.K. Whitaker, who identified the need for independent and in-depth research analysis to provide a robust evidence base for policymaking in Ireland.

Since then, the Institute has remained committed to independent research and its work is free of any expressed ideology or political position. The Institute publishes all research reaching the appropriate academic standard, irrespective of its findings or who funds the research.

The quality of its research output is guaranteed by a rigorous peer review process. ESRI researchers are experts in their fields and are committed to producing work that meets the highest academic standards and practices.

The work of the Institute is disseminated widely in books, journal articles and reports. ESRI publications are available to download, free of charge, from its website. Additionally, ESRI staff communicate research findings at regular conferences and seminars.

The ESRI is a company limited by guarantee, answerable to its members and governed by a Council, comprising 14 members who represent a cross-section of ESRI members from academia, civil services, state agencies, businesses and civil society. The Institute receives an annual grant-in-aid from the Department of Public Expenditure and Reform to support the scientific and public interest elements of the Institute's activities; the grant accounted for an average of 30 per cent of the Institute's income over the lifetime of the last Research Strategy. The remaining funding comes from research programmes supported by government departments and agencies, public bodies and competitive research programmes.

Further information is available at www.esri.ie. 


\section{THE AUTHORS}

Samantha Arnold was at the time of writing this report a Post-Doctoral Research Fellow at the Irish National Contact Point of the European Migration Network (EMN), within the ESRI. Emma Quinn is the Head of the Irish National Contact Point of the EMN. Sarah Groarke is Policy Officer with EMN Ireland. Fran McGinnity is an Associate Research Professor at the ESRI and Senior Research Advisor for EMN Ireland. Christina Durst was an Intern at EMN Ireland.

\section{ACKNOWLEDGEMENTS}

In compiling this study, valuable assistance was received from representatives of the Office of the Promotion of Migrant Integration in the Department of Justice and Equality, the Irish Naturalisation and Immigration Service in the Department of Justice and Equality, the Department of Business, Enterprise and Innovation, the Department of Education and Skills, the Department of Employment Affairs and Social Protection, Education and Training Boards Ireland, Crosscare Migrant Project, Business in the Community Ireland - Employment for People from Immigrant Communities, New Communities Partnership, Immigrant Council of Ireland, Migrant Rights Centre Ireland, Migrant Teachers Project and the Public Appointments Service. We also acknowledge the useful comments and suggestions received from the referees. Finally, thanks are due to our colleagues Elaine Byrne and Sarah Burns at the ESRI. We are grateful to everyone who shared their expertise with us for the purpose of writing this study. Thanks also to Colm O'Dwyer who provided research assistance on the study template.

\section{ABOUT THIS REPORT}

This European Migration Network study looks at labour market integration policy and measures for non-EU nationals in Ireland in the period 2014-2019. It identifies existing policies and examples of public, private and community sector practices. The report consists of information gathered by way of a common template, primarily for an overview, EU-level synthesis report: Labour market integration of third-country nationals in EU Member States.

This report has been accepted for publication by the Institute, which does not itself take institutional policy positions. All ESRI Research Series reports are peer reviewed prior to publication. The authors are solely responsible for the content and the views expressed do not represent the position of the Economic and Social Research Institute, the Irish Naturalisation and Immigration Service, the Department of Justice and Equality, or the European Commission, Directorate-General Migration and Home Affairs. 



\section{TABLE OF CONTENTS}

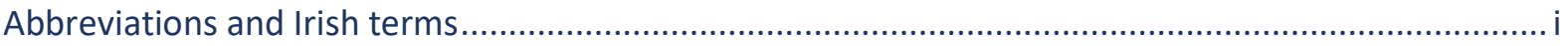

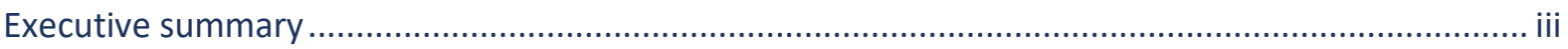

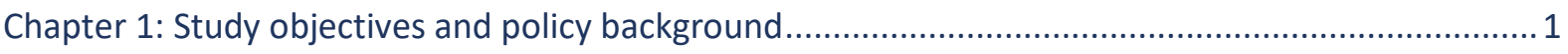

1.1 Objectives and background to the study ..................................................................... 1

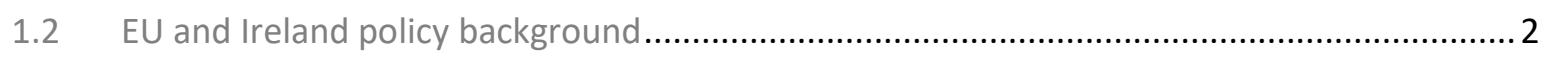

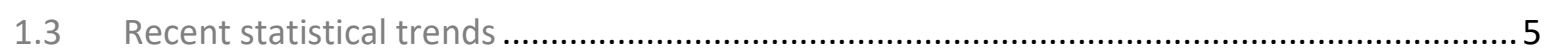

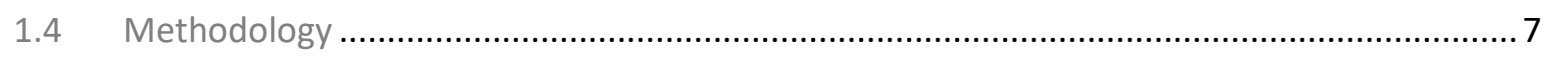

Chapter 2: Overview of national labour migration and integration policy......................................... 9

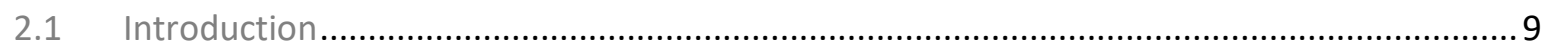

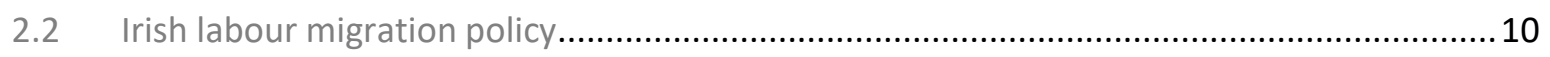

2.2.1 Employment permit system ......................................................................... 10

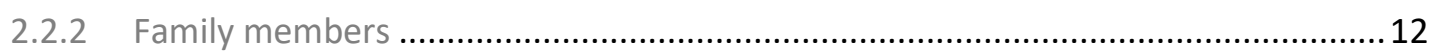

2.3 Integration in the mainstreamed system ................................................................. 13

2.3.1 The current migrant integration strategy ............................................................. 14

2.3.2 Data for monitoring integration ..................................................................... 17

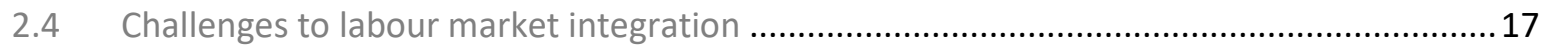

2.4.1 Under-employment, lack of career progression and low pay .................................. 18

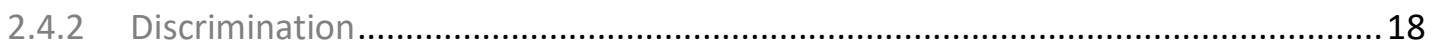

2.4.3 Other barriers to accessing employment …........................................................... 19

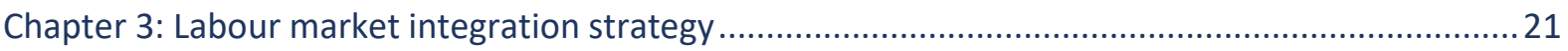

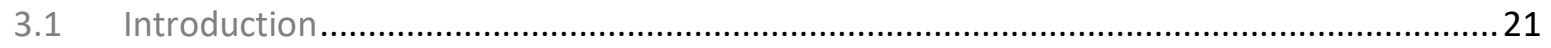

3.2 Institutional framework for labour market integration under the migrant integration

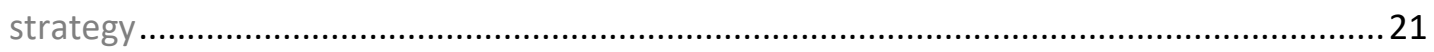

3.3 Labour market integration actions under the migrant integration strategy ........................22

3.3.1 Education, training and English for speakers of other languages (actions 39, 40)... 23

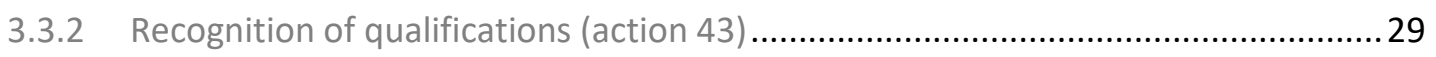

3.3.3 Seeking employment and self-employment (actions 41-42 and 44-47).................31

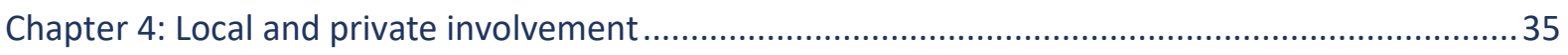

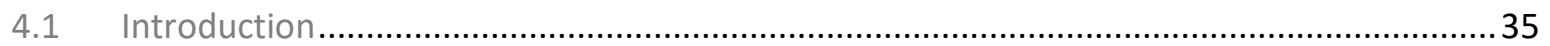

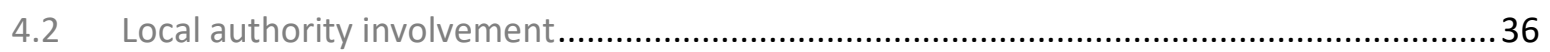

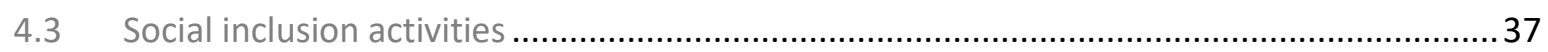




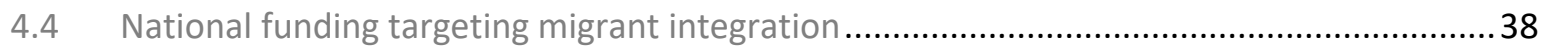

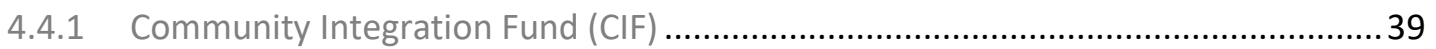

4.4.2 National Funding to Promote the Integration of Immigrants ................................. 40

4.4.3 Integration projects funded through the ESF (PEIL) ............................................ 42

4.4.4 EU Asylum, Migration and Integration Fund ........................................................ 45

4.4.5 Future and continuation of funding administered by OPMI ................................... 47

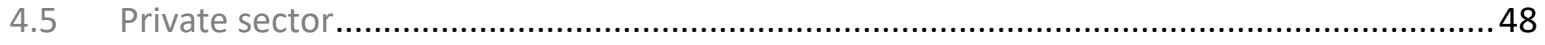

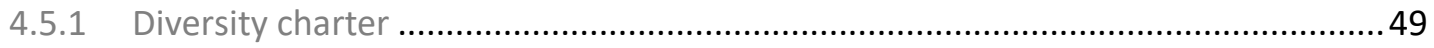

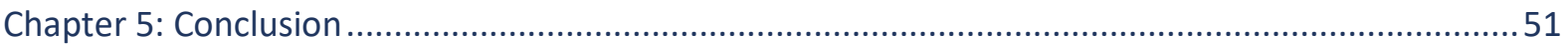

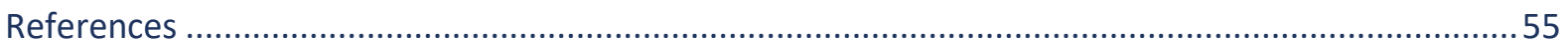

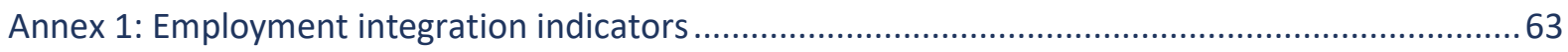

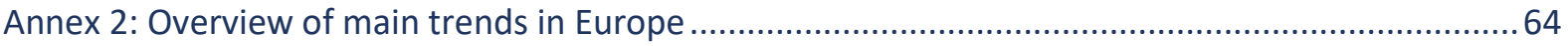




\section{LIST OF TABLES}

Table $1.1 \quad$ Non-EEA residence permissions valid in Ireland, 2014-2017.................................

Table 3.1 Employment and Pathways to Work: Status of actions, April 2019 ..........................23

Table A.1 Non-EEA residence permits valid in EU, 2-14-2017................................................64

\section{LIST OF FIGURES}

Figure $1.1 \quad$ Employment permits issued, 2007-2018 ….......................................................

Figure 2.1 Actions (n.) of the current migrant integration strategy, by bodies responsible for its

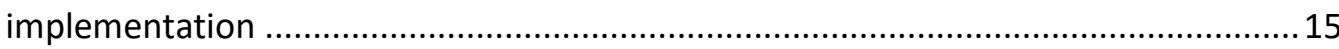

Figure 3.1 Organogram of the institutional framework for labour market integration as indicated by the migrant integration strategy (2017-2020) 22

\section{LIST OF BOXES}

Box 3.1 Employment for People from Immigrant Communities (EPIC)

Box 3.2 Building Better Futures - Building Social Enterprise with Migrant Women

Entrepreneurs

Box 4.1 Projects funded under National Funding to Promote the Integration of Immigrants 41

Box 4.2 PEIL integration and employment of migrants projects .44

Box 4.3 Labour market integration projects for non-EU nationals funded under AMIF ......... 46

Box 4.4

Welcome to Work 



\section{ABBREVIATIONS AND IRISH TERMS}

\begin{tabular}{|c|c|}
\hline AMIF & Asylum, Migration and Integration Fund \\
\hline An Garda Síochána & Ireland's National Police Service \\
\hline $\mathrm{BITCl}$ & Business in the Community Ireland \\
\hline CEFR & Common European Framework of Reference for Languages \\
\hline $\mathrm{CIF}$ & Community Integration Fund \\
\hline CSO & Central Statistics Office Ireland \\
\hline CSR & Corporate social responsibility \\
\hline $\mathrm{CV}$ & Curriculum vitae \\
\hline DCU & Dublin City University \\
\hline DBEI & Department of Business Enterprise and Innovation \\
\hline DES & Department of Education and Skills \\
\hline DEASP & Department of Employment Affairs and Social Protection \\
\hline DJE & Department of Justice and Equality \\
\hline DRCD & Department of Rural and Community Development \\
\hline EEA & European Economic Area \\
\hline EMN & European Migration Network \\
\hline EPIC & Employment for People from Immigrant Communities \\
\hline ESF & European Social Fund \\
\hline ESOL & English for speakers of other languages \\
\hline ESRI & Economic and Social Research Institute \\
\hline ETB & Education and Training Board \\
\hline ETBI & Education and Training Boards Ireland \\
\hline EU & European Union \\
\hline $\mathrm{ICl}$ & Immigrant Council of Ireland \\
\hline ICTU & Irish Congress of Trade Unions \\
\hline INIS & Irish Naturalisation and Immigration Service \\
\hline IT & Information and technology \\
\hline JUMP & Jobs for U, Migrants Processing Programme \\
\hline LEADER & European Union Initiative for Rural Development \\
\hline LEO & Local enterprise office \\
\hline LGBT & Lesbian, gay, bisexual and transgender \\
\hline MAP & Migrant Access Programme \\
\hline
\end{tabular}


MIPEX

$\mathrm{MRCl}$

MUKISA

NARIC

NASC

NCP

NGO

OECD

OPMI

QNHS

QQI

PAS

PEIL

PPSN

SEDCo

SICAP

SOLAS

TCN

Teachta Dála (T.D.)

UNHCR

UK
Migration Integration Policy Index

Migrant Rights Centre Ireland

Mobilising Urban Knowledge and Connectedness Through

Integration and Social Achievement

National Academic Recognition Information Centre

Irish Immigrant Support Centre

New Communities Partnership

Non-governmental organisation

Organisation for Economic Co-operation and Development

Office for the Promotion of Migrant Integration

Quarterly National Household Survey

Quality and Qualifications Ireland

Public Appointments Service

Programme for Employability, Inclusion and Learning

Personal public service number (Irish social security number)

Social Enterprise Development Company

Social Inclusion and Community Activation Programme

Further Education and Training Authority

Third-country national

Member of Parliament

Office of the United Nations High Commissioner for Refugees United Kingdom 


\section{EXECUTIVE SUMMARY}

Increases in immigration inflows to both the European Union (EU) and Ireland between 2014 and 2016, due in part to the 'refugee and migrant crisis', have resulted in an increased focus on integration policies, outcomes and measures, including in the area of labour market integration. Employment is crucial for the integration of migrants into the economic and social life of their host country, so labour market integration is a very important part of integration policy (European Commission, 2016). In recent years, many Member States have updated existing labour market integration policies or have developed new ones. Ireland, like the majority of EU Member States (EMN, 2019), pursues a policy of mainstreaming service provision in the area of integration, with targeted initiatives to meet specific needs.

This study first considers labour migration policy, which manages and shapes overall access of non-European Economic Area (EEA) nationals to the Irish labour market. ${ }^{1}$ Under the employment permits system administered by the Department of Business, Enterprise and Innovation (DBEI), non-EEA nationals may apply to access the Irish labour market. The report then looks at specific policies and measures which aim to improve labour market integration for non-EU nationals living in Ireland. The focus is on labour integration measures for regularly staying non-EU nationals with a right to work. Measures specifically targeting non-EEA students, graduates, asylum seekers and beneficiaries of international protection are beyond the study scope. The effect of general labour market and social policy provision in Ireland on labour market integration is also outside the scope. Examples of public and private sector practices are discussed together with examples of community sector practices that receive public funds.

\section{MIGRANT INTEGRATION STRATEGY AND MONITORING INTEGRATION}

Ireland's current migrant integration strategy, The migrant integration strategyA blueprint for the future, runs from January 2017 to December 2020. It comprises a framework for government action, with the aim of enabling all migrants to actively participate in Irish communities, workplaces and politics. In the strategy, integration is defined as the 'ability to participate to the extent that a person needs and wishes in all of the major components of society without having to relinquish his or her own cultural identity' (Department of Justice and Equality, 2017a). The primary focus is on ensuring the equitable provision of public services within a mainstreamed system. ${ }^{2}$ While EU integration policy refers to third-country

Irish labour migration policy applies to persons from outside the EEA. For the purposes of this study, EU/non-EU nationals are taken to include/exclude EEA nationals.

Interview with OPMI, May 2018. 
nationals, all non-Irish and second-generation Irish nationals fall within the scope of the migrant integration strategy. ${ }^{3}$ As McGinnity et al. (2018a) note, it has brought new energy and focus into efforts to integrate migrants into Ireland.

The Office for the Promotion of Migrant Integration (OPMI) has a crossdepartmental mandate to lead and co-ordinate migrant integration policy, while the delivery of integration services rests with individual government departments and agencies. The cross-departmental approach was highlighted by OPMI as an important and challenging aspect of ensuring collective implementation of the strategy and integration policy in general. ${ }^{4}$ The Migrant Integration Strategy Monitoring and Coordination Committee was established under the Minister of State for Justice at the Department of Justice and Equality (DJE) with special responsibility for equality, immigration and integration, which includes representatives of government departments, public bodies, local authorities, and non-governmental organisations (NGOs).

Crosscare noted that it is up to each government department and agency to decide the extent to which they engage with the strategy, and that this is a challenge for implementation. ${ }^{5}$ Other challenges, identified by a number of stakeholders, include the broad nature of the actions, alongside an absence of clear targets. ${ }^{6}$ It was also noted that some employers and politicians focus on addressing labour and skills shortages through attracting new migrants, rather than the labour market integration of migrants already living in Ireland. ${ }^{7}$

There has been progress in recent years on monitoring the integration of migrants in Irish society. Monitoring outcomes is important given the focus on mainstream policy in the delivery of services. The Monitoring report on integration series, published by the Economic and Social Research Institute (ESRI) and the DJE (McGinnity et al., 2018a), presents a range of integration indicators derived from national-level data. An Integration Data Working Group was established to examine data gaps in relation to integration. Their work has recently been informed by a mapping study on the availability of quantitative data relevant to the study of migrant integration in Ireland (Fahey et al., 2019).

\section{EMPLOYMENT AND PATHWAYS TO WORK}

Research on the experience of migrants in the Irish labour market has identified a number of challenges. Non-Irish nationals, Black non-Irish nationals and individuals

\footnotetext{
In practice, it can be difficult to identify some groups. In particular, second-generation Irish nationals are not identified in either administrative or survey data in Ireland (Fahey et al., 2019). Interview with OPMI, May 2018.

Interview with Crosscare, April 2018.

Interviews with Crosscare and BITCI, April 2018; ICI, May 2018.

Interviews with Crosscare, BITCI, April 2018; MRCI and ICI, May 2018.
} 
of African origin face higher rates of work-related discrimination than Irish nationals (Kingston et al., 2012; Kingston et al., 2015, McGinnity et al., 2018c). Other challenges identified include: low pay (MRCl, 2015b); over-qualification; lack of progression, and exploitation ( $\mathrm{MRCl}, 2015 \mathrm{a}$ ); inadequate English language skills; weak network; lack of recognition of qualifications; and potential need to up-skill (O'Connell, 2018; Gusciute et al., 2016).

A number of non-governmental organisations (NGOs) highlighted both the employment permit system and government policy regarding the rights to work for family members as being problematic for labour market integration. ${ }^{8}$ In particular, Migrant Rights Centre Ireland ( $\mathrm{MRCl}$ ) stated that the use of employerspecific permits and the salary threshold can lead to underemployment of non-EU nationals (MRCl, 2015b).

Ten specific actions on labour market integration are set out under the heading 'Employment and pathways to work' in the migrant integration strategy. ${ }^{9} \mathrm{~A}$ report published by SOLAS and Educational and Training Boards Ireland (ETBI) as part of efforts to address one of these (action 40) noted that the provision of English for speakers of other languages (ESOL) programmes has developed in the absence of a national strategy. The recognition of non-EU nationals' qualifications was raised by many stakeholders as a challenge to implementing labour market integration policies. ${ }^{10}$ Stakeholders welcomed action 43 , dedicated to promoting the Quality and Qualifications Ireland (QQI) system, but called for further efforts from Irish professional bodies, and increased promotion of the QQI. While all ETBs provide accreditation through QQI, SOLAS and ETBI highlighted that QQI language awards have very limited recognition outside of ETBs (Kett, 2018). ${ }^{11}$

Action 41 of the migrant integration strategy tasks the Department of Employment Affairs and Social Protection (DEASP) with ensuring appropriate levels of engagement with migrants registered as jobseekers. On this issue, recent research by Crosscare (2018) has shown that migrant customers with language support needs may not be accessing, or even be aware of, appropriate interpreter services provided by DEASP services. DEASP reported that it has since increased efforts to encourage staff to make use of available translation and interpretation services where required. ${ }^{12}$

Interviews with Crosscare, April 2018; ICI, MRCI, NCP, May 2018.

In May 2019 OPMI noted that one of these actions is marked complete, five are considered to be 'on track' and four have 'minor problems or delays'.

Interviews with Crosscare, BITCl, April 2018; ICl, MRCl, NCP, May 2018.

Interview with ETBI, May 2018 (regarding ETB provision of accreditation through QQI).

Comments received from DEASP, June 2019. 
In another 2018 study, the DEASP addressed action 42 of the strategy - to analyse the extent to which the level of joblessness among jobseekers of African origin exceeds that of other groups and to determine actions to address this. Using data from the Jobseekers Longitudinal Dataset (JLD), it showed that African jobseekers have the lowest employment rate among all nationality groups after 12 months.

Action 45 tasks the Department of Public Expenditure and Reform (DPER) with ensuring that one per cent of the public workforce are from an ethnic minority background. While the majority of public sector jobs are limited to EEA citizens, PAS noted that increased outreach may ensure that non-EU nationals who may later acquire Irish/EEA citizenship are more aware of opportunities in the public sector.

Just over half of local authorities reported that their local enterprise office (LEO) had already undertaken targeted initiatives or had proposals under consideration to address action 47: to engage with migrant entrepreneurs.

\section{LOCAL LEVEL AND PRIVATE SECTOR INVOLVEMENT}

The implementation of relevant actions assigned to local authorities occurs at local government level with oversight by OPMI, but OPMI noted that collating information on activities has proven challenging. ${ }^{13}$ At present, OPMI does not make a direct input regarding integration matters when it comes to local authorities' budget planning processes. ${ }^{14}$ Under the migrant integration strategy, local authorities are required to update their own migrant integration strategies between 2017 and 2020. In July 2018, 21 of 31 local authorities had a migrant integration strategy in place or had one at some point in the past; however, just three had a current migrant integration strategy (Immigrant Council of Ireland, 2018). Crosscare commented that many relevant projects exist at local level, or within the community, that are not reported on under the national migrant integration strategy. Crosscare also noted the absence of a direct link between the strategy and the Social Inclusion Community Activation Programme (SICAP) 20182022 or reference within the strategy to local partnerships, two important initiatives for community-level social inclusion in Ireland. ${ }^{15}$

In recent years, there has been an increase in integration-related activities, as well as an increase in public funds available for integration activities specifically for refugees and other migrants. Funding through national OPMI-administered programmes has been available under the Community Integration Fund (CIF), National Funding to Promote the Integration of Immigrants, the European Social

Consultation with OPMI, July 2018.

Interview with OPMI, May 2018.

Interview with Crosscare, April 2018. 
Fund Programme for Employability, Inclusion and Learning (PEIL) and the European Asylum, Migration and Integration Fund. An important issue for both local and national programmes, however they are funded, is both their reach (how many participants are included?) and their effectiveness (do they improve the labour market outcomes for participants?). Programme evaluations are crucial to any policy learning. An independent interim evaluation of Ireland's national programme under the EU Asylum, Migration and Integration Fund (AMIF) 20142020 was carried out in December 2017. Interim and final reports have been received and reviewed for other funding initiatives of the OPMI, including projects in the National Funding to Promote the Integration of Immigrants and CIF 2017. ${ }^{16}$

Private sector involvement in the strategy design and implementation is somewhat limited. Potential opportunities may lie in the current national plan for corporate social responsibility (CSR) (DBEI, 2017), in which OPMI is involved. There are nevertheless some examples of private sector businesses that provide publiclyfunded labour market integration support services to migrants in Ireland. Examples include EPIC, Welcome to Work by Seetec, ETBI's Skills for Work programme and MRCl's migrant women's entrepreneur project. The European Migration Network (EMN) (2019) noted that the private sector can add value to national labour market integration strategies, including by meeting gaps wherever public measures fall short; for example, due to a lack of or insecure public funding.

\section{INTEGRATION POLICY IN THE MAINSTREAM CONTEXT}

The success of migrant integration policy, including the national migrant integration strategy, in terms of the labour market integration of non-EU nationals, relies on both engagement and effective implementation by individual government departments, agencies and local authorities. Those involved in service delivery need to be aware of their responsibility to migrants, and the importance of labour market integration for this group. Employment permit policy for non-EU nationals also needs to work with the objectives of the strategy. Lack of clarity around work rights will inhibit labour market integration, as both jobseekers and employers alike may be unaware of who has permission to work.

Of course, labour market integration is about more than the migrant integration strategy. The labour market outcomes of non-EU nationals will be influenced by how effectively both general labour market and social inclusion policy in Ireland serves the needs of this group of migrants. To understand labour market integration outcomes for non-EU nationals, one needs to take account of how 
viii | Labour market integration of non-EU nationals in Ireland

mainstream agendas are themselves addressing labour market integration, but doing so was beyond the scope of this report. 


\section{CHAPTER 1}

\section{Study objectives and policy background}

\subsection{OBJECTIVES AND BACKGROUND TO THE STUDY}

This study looks at policies and measures that aim to improve labour market integration for non-EU nationals living in Ireland. ${ }^{17}$ As noted by the European Commission in their Action plan on the integration of third-country nationals in 2016, 'Employment is a core part of the integration process. Finding a job is fundamental to becoming part of the host country's economic and social life, ensuring access to decent accommodation and living conditions as well as economic inclusion' (European Commission, 2016).

This report is part of an EU-wide study which focuses on specific policies, strategies and models for the labour market integration of non-EU nationals. This Irish report contains information gathered for the EU-level report, Labour market integration of third-country nationals in EU Member States. The current study identifies existing policies and examples of public and private sector practices in Ireland. Examples of community sector practices that receive public funds are also discussed. This study focuses on the national migration strategy, The migrant integration strategy: A blueprint for the future (Department of Justice and Equality), which runs from 2017 to 2020, as the key policy statement on migrant integration in Ireland. However, it is acknowledged that migrant integration policy does not stop with the strategy. Ireland's mainstreamed approach to integration means that service-providing departments and agencies also play a key role. Other important programmes and initiatives for community development at local level in Ireland also impact significantly, such as the Social Inclusion Community Activation Programme (SICAP) 2018-2022. Finally, it is important to note that the rules governing which non-EEA nationals can work in Ireland and under what conditions form an important backdrop to any measures to support labour market integration.

The focus is on labour integration measures for regularly staying non-EU nationals with a right to work. The target group includes labour migrants and non-EU national family members, both of EU and non-EU nationals. Measures specifically targeting students, graduates, asylum seekers and beneficiaries of international protection are beyond the scope of this study and are therefore not included. However, mainstream organisations and measures accessed by the excluded groups and which benefit non-EU nationals generally are discussed. In addition, 
measures that address the labour market integration of vulnerable or specific groups such as women are highlighted. The majority of policies and measures in Ireland are mainstreamed, but some measures target refugees and asylum seekers specifically. There are no examples of integration measures in Ireland focusing exclusively on non-EU nationals with a migrant status other than international protection. The temporal scope of the study is 2014 to 2019.

The remainder of this chapter (Sections 1.2-1.4) provides background to the study, including the policy context, a discussion of main trends and the study methodology. Chapter 2 looks at national labour migration and integration policy, as well as EU integration policy. In Chapter 3, the employment-related actions in the migrant integration strategy are discussed. The government departments and agencies responsible are outlined along with progress on the relevant actions. Chapter 4 looks at local-level implementation of labour market integration policy that specifically targets migrants. National funding administered by Office for the Promotion of Migrant Integration (OPMI), which was made available to support specific labour market integration measures and private sector initiatives, is also outlined. The measures discussed in Chapters 3 and 4 are national insofar as they receive national funding.

\subsection{EU AND IRELAND POLICY BACKGROUND}

Integration policy falls clearly within the national competence of Member States. However, arising from the Treaty of Lisbon in 2007, European institutions have a mandate to 'provide incentives and support for the action of Member States with a view to promoting the integration of third-country nationals'. ${ }^{18}$ Recent increases in immigration inflows, due in part to the 'refugee and migrant crisis', in the European Union (EU) and in Ireland 2014-2016, have resulted in an increased focus on integration policies, outcomes and measures, including in the area of labour market integration. Many Member States have updated existing labour market integration policies or developed new ones. During this period, new or better forms of cooperation were developed between different governmental bodies, stakeholders and services, as well as increased monitoring mechanisms of integration programmes and measures (EMN, 2019).

Before the Treaty of Lisbon, in 2004 the Justice and Home Affairs Council adopted the 'Common basic principles for immigrant integration policy' in the EU. Integration was defined as 'a dynamic two-way process of mutual accommodation by all immigrants and residents of Member States'. Principle 3 refers to 
employment as an important way for immigrants to contribute to and participate in Member State societies (Council of the European Union, 2004).

In 2010, the EU adopted the Zaragoza Declaration to complement integration policy, with a set of comparable indicators to support monitoring and evaluation of progress on integration across Member States. The European Commission emphasised that 'employment is a vital part of the integration process, and efforts in education are essential in helping immigrants to become successful and more active participants in society'. The Zaragoza Declaration includes three recommended indicators for measuring labour market activity: employment rate; unemployment rate; and activity rate. It also identifies two further indicators, where data permit: self-employment and over-qualification (see Annex 1). ${ }^{19}$

In 2011, the European Commission published the European agenda for the integration of third-country nationals, in which the European Commission reiterated that 'participating in the labour market is one of the best and most concrete ways to integrate in society' (European Commission, 2011). The agenda was followed by the Action plan on integration of third-country nationals in 2016, in which the European Commission reiterated the importance of employment for migrant integration (European Commission, 2016).

In Ireland, like in the majority of EU Member States (EMN, 2019), integration policy is mainstreamed, meaning that government departments and agencies, such as the Department of Education and Skills (DES) and the Department of Employment Affairs and Social Protection (DEASP), are responsible for integrating immigrants into Irish society via the delivery of standard public services. The first government report on integration, Integration: A two way process, was published in 1999. It describes integration as a two-way process and defines integration as 'the ability to participate to the extent that a person needs and wishes in all of the major components of society, without having to relinquish his or her own cultural identity' (Department of Justice, Equality and Law Reform, 1999). Integration initiatives and the development of an overall migrant integration strategy were put on hold and only came back on the agenda in 2014, coinciding with increased resource allocation to OPMI (Glynn, 2014).

Integration: A two way process was followed by The migrant integration strategy: A blueprint for the future. Published in 2017, this current strategy runs to December 2020 and is the first comprehensive strategy on integration in Ireland (Department of Justice and Equality, 2017a). The definition of integration was carried over from the 1999 publication. OPMI noted that the current strategy was 
drafted in accordance with the 'Common basic principles for immigrant integration'; OPMI views the thematic areas included in the strategy as broadly corresponding to the Zaragoza indicators. ${ }^{20}$

In Ireland, the Zaragoza indicators are utilised to measure the integration of (EU and non-EU) migrants in the areas of employment, education, social inclusion and active citizenship in the Monitoring report on integration series, published regularly by the Economic and Social Research Institute (ESRI) and Department of Justice and Equality (DJE) (McGinnity et al., 2011, 2012, 2013, 2014, 2018a; Barrett et al., 2017).

The migrant integration strategy acknowledges that employment enhances the integration process, setting out several actions related to labour market integration. It contains 76 actions to be undertaken by 21 government departments and agencies, as well as non-governmental organisations (NGOs), political parties and other organisations. Some ten actions relate specifically to labour market integration. While EU integration policy refers to third-country nationals (TCNs) and excludes EU nationals who move to other EU countries (Barrett et al., 2017), all non-Irish and second-generation Irish nationals fall within the scope of Irish integration policy. ${ }^{21}$ Murphy et al. (2017) described the current strategy as a tool targeting 'long-term' migrants.

Labour migration policy impacts migrant labour market integration in that it determines who may access the labour market and under what conditions. In Ireland, labour migration is also largely a national competence. Non-EEA nationals who are required to hold an employment permit may apply under the employment permits system, which is managed on a statutory basis by the Department of Business Enterprise and Innovation (DBEI). The DBEI regulates the labour market needs test, the conditions under which permit holders may move jobs and periods of renewal. The DJE is responsible for rules regarding the entry into the State of non-EU migrants and the labour market access of migrants whose presence in the State falls outside the employment permits system.

Various initiatives and projects take place within the community, often as part of social inclusion activities that impact locally on migrant integration. Social inclusion policy is led by the DEASP and the Department of Rural and Community Development (DRCD). The Updated national action plan for social inclusion 20152017 lists the promotion of migrant integration, including economic integration, among its goals (Department of Social Protection, 2016).

$20 \quad$ Interview with OPMI, May 2018.

21 This distinction is important when discussing Irish integration strategies in relation to increasing EU immigration to Ireland. 
The provision of further education and training programmes is coordinated by SOLAS, the further education and training authority, which operates under the aegis of the DES, in coordination with Ireland's 16 education and training boards (ETBs). English for speakers of other languages (ESOL) is provided by ETBs as part of their adult programmes. However, English language provision for adult migrants in Ireland has developed in the absence of an overall national strategy or policy initiative (Kett, 2018).

Despite EU and Irish integration policy, non-EU nationals continue to fare worse than EU citizens in employment and unemployment. ${ }^{22,23}$ In general, non-EU nationals tend to have lower employment rates and higher unemployment rates than Irish nationals. Data from early 2017 show that African nationals form a particularly disadvantaged group in Ireland, with much lower employment and activity rates than other immigrant groups, as well as higher unemployment (McGinnity et al., 2018a). That said, the continued growth of employment and falling unemployment in Ireland during the period this study focuses on (20142019) provides a favourable labour market context for the integration of non-EEA migrants. ${ }^{24}$

\subsection{RECENT STATISTICAL TRENDS}

As at 1 January 2018, there were 201,771 people born outside the EU resident in Ireland, accounting for four per cent of the population. ${ }^{25}$ Table 1.1 shows the total residence permissions issued to non-EU nationals in Ireland between 2014 and 2017.

This study looks at labour market integration policies and measures for non-EU nationals with a legal right to work. Non-EU nationals with residence permissions issued for remuneration reasons fall into the scope of this study. Persons with residence permissions issued for family reasons may also be entitled to access the labour market, but may be required to apply for an employment permit (discussed below). Finally some persons in the category 'Other' may fall into the scope of the study. ${ }^{26}$

This includes non-EU nationals who become EU citizens.

The action plan also states that TCNs fare worse in education and social inclusion.

The seasonally adjusted unemployment rate in Ireland fell from 12.7 in March 2014 to 5.4 in March 2019; see

https://www.cso.ie/multiquicktables/quickTables.aspx?id=mum01.

Eurostat [migr_pop3ctb].

This category contains a diverse group of persons with permissions that do not fit into the main categories, including individuals who have permission to stay in Ireland without limits on the time they can remain here, dual Irish citizens and persons granted permission to remain under Section 3 of the Immigration Act 1999 (Fahey et al., 2019). 
TABLE 1.1 NON-EEA RESIDENCE PERMISSIONS VALID IN IRELAND, 2014-2017

\begin{tabular}{|l|r|r|r|r|r|r|}
\hline Residence permission reason & 2014 & 2015 & 2016 & 2017 & $\% 217$ \\
\hline Education & 41,225 & 43,540 & 35,323 & 39,779 & $24 \%$ \\
\hline Family & 23,134 & 25,632 & 27,243 & 30,184 & $23 \%$ \\
\hline Other & 24,213 & 25,365 & 25,729 & 29,987 & $20 \%$ \\
\hline Remunerated activities & 15,831 & 17,947 & 20,973 & 26,133 & $2 \%$ \\
\hline International protection & 1,166 & 1,430 & 1,659 & 1,983 & $100 \%$ \\
\hline Total & 105,569 & 113,914 & 110,927 & 128,066 & \\
\hline
\end{tabular}

Source: Eurostat: [migr_resvalid]

Permissions issued for 'family', 'other' and 'remunerated activities' increased annually between 2014 and 2017.

Following a period of decline in labour market conditions during the 2008-2012 recession, recent years have seen a substantial recovery in the Irish labour market. These trends have been reflected in the number of employment permits issued to non-EEA nationals in Ireland. Note that many permits are issued for an initial twoyear period and are renewed at two to three year intervals. The figures are therefore lower than those in Table 1.1. 


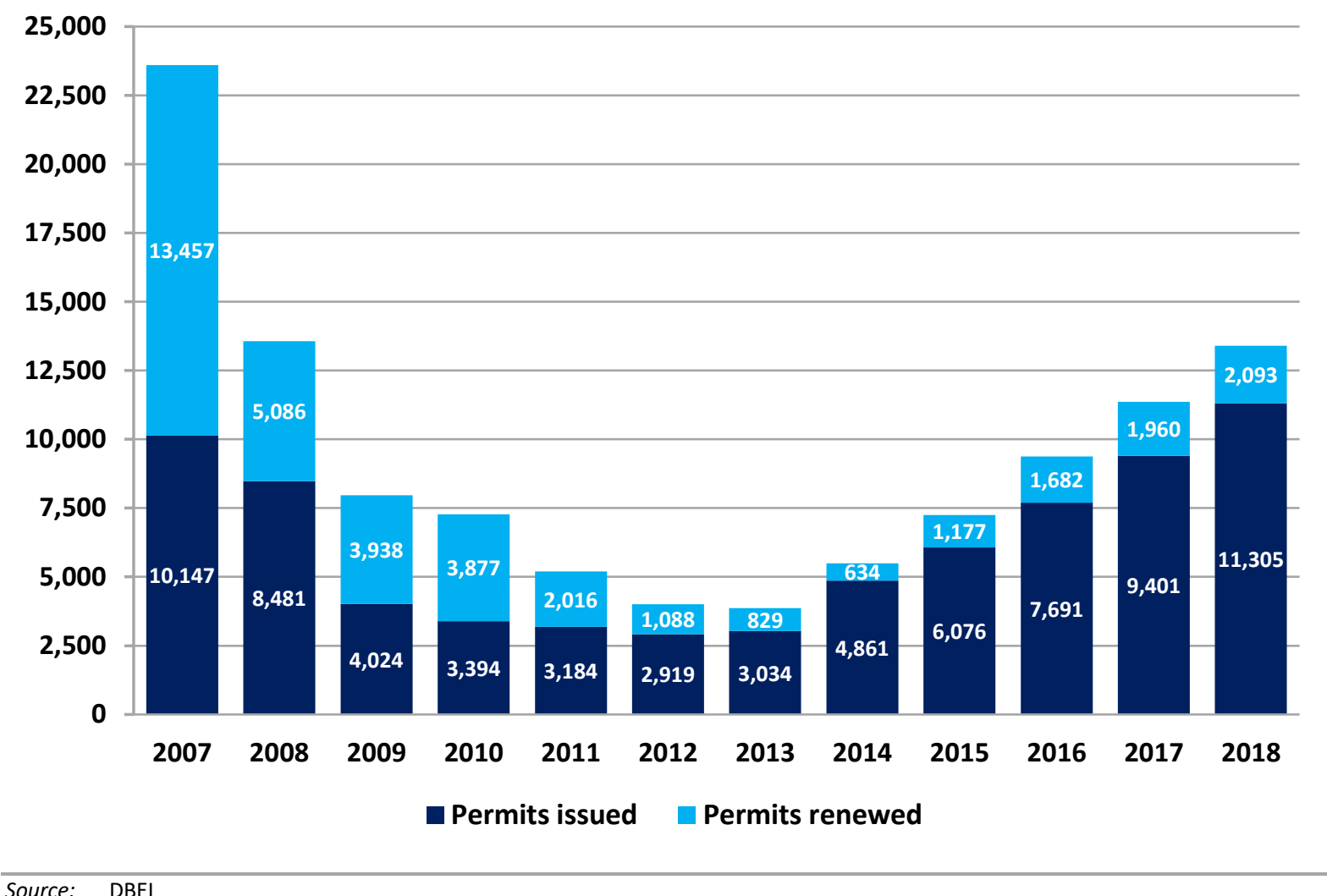

Data on statistical trends in the EU are discussed in Annex 2.

\subsection{METHODOLOGY}

This study examines national policy and practice targeting the labour market integration of non-EU nationals in Ireland. The scope of this study is limited to first generation non-EU nationals with the right to work in Ireland, including family members of non-EU and EU citizens. Integration policy and measures designed specifically for beneficiaries of international protection, asylum seekers and students or graduates are excluded from the study.

Desk research was undertaken at the outset, including a review of existing academic and policy-based literature. A large amount of information was obtained from government publications and websites, in particular from OPMI. ${ }^{27}$ Interviews were then conducted with representatives of OPMI, Education and Training Boards Ireland (ETBI), Crosscare Migrant Project, Business in the Community Ireland (BITCI) - Employment for People from Immigrant Communities (EPIC), New Communities Partnership (NCP), Immigrant Council of Ireland (ICI), Migrant Rights Centre Ireland (MRCI) and the Public Appointments Service (PAS). Due to a delay

$27 \quad$ See www.integration.ie. 
in publication, the study was updated with information from OPMI in April 2019 and from DBEI in May 2019. Minor comments were provided by the Irish Naturalisation and Immigration Service (INIS), DEASP and DES in May and June 2019. The report was internally and externally reviewed.

The information used to produce this report was gathered according to commonly agreed European Migration Network (EMN) specifications developed to facilitate comparability across countries. The focus of the EU-wide study is on specific policies, strategies and models for the labour market integration of non-EU nationals. Contributing Member States were also asked to identify 'good or promising practices' ${ }^{28}$

The EMN is tasked with producing studies on topics of relevance to policymakers at national and EU levels, in order to meet long- and short-term information needs. ${ }^{29}$ Topics may be proposed for in-depth strategic studies with long-term relevance, or for shorter studies, responding to immediate information needs. Each EMN National Contact Point produces a national report and a comparative synthesis report is then produced, which brings together the main findings from the national reports and places them within an EU perspective. The synthesis report for the current study is called Labour market integration of third-country nationals in EU Member States..$^{30}$

EMN (2018). Labour market integration of third-country nationals in EU Member States: Common template. Council Decision 2008/381/EC establishing the EMN was adopted on 14 May 2008.

Available at: https://ec.europa.eu/home-

affairs/sites/homeaffairs/files/00_eu_labour_market_integration_final_en.pdf 


\section{CHAPTER 2}

\section{Overview of national labour migration and integration policy}

\section{$2.1 \quad$ INTRODUCTION}

Despite increased attention to migrant integration in recent years, research has shown that migrants face a number of challenges in the Irish labour market, including lack of career progression (McGinnity et al., 2018c; MRCI, 2015a; Barrett and Duffy, 2008), discrimination (McGinnity et al., 2018c), and poor recognition of qualifications and potential need to up-skill (O'Connell, 2018; Gusciute et al., 2016). The Office for the Promotion of Migrant Integration (OPMI) observed that the publication of The migrant integration strategy: A blueprint for the future is evidence of the political priority accorded to migrant integration, including labour market integration. ${ }^{31}$ Stakeholders also commented that the availability of funding for the provision of further education and training and labour market integration projects indicates that labour market integration is a political priority (see Chapter 4). ${ }^{32}$ However, non-governmental organisations (NGOs) consulted for this study expressed the view that labour market integration of non-EU nationals, specifically, is not afforded sufficient priority, and that this is reflected in the lack of debate or focus on integration at a political level. ${ }^{33}$ These stakeholders see more emphasis being placed at a political level on responding to labour shortages through attracting highly-skilled migrants in certain sectors of the labour market, with less focus being placed on the integration of migrants and their families post-arrival and the labour market integration of those migrants who are already in Ireland but are unemployed or under-employed. ${ }^{34}$

Labour migration policy manages and shapes overall access of non-European Economic Area (EEA) nationals to the Irish labour market, while employmentrelated actions in the migrant integration strategy attempt to address some challenges faced by migrants who have permission to work. Recent changes to the labour migration regime also respond to specific challenges. Section 2.2 provides a broad overview of Irish policy both on labour migration and on labour market integration. Section 2.3 considers integration in the mainstreamed system and section 2.4 briefly reviews existing research on challenges to labour market integration in Ireland.

Interview with OPMI, May 2018.

Interviews with Crosscare, April 2018; OPMI, ETBI, NCP, ICl and MRCI, May 2018.

Interviews with Crosscare, April 2018; ICl, May 2018.

Interviews with Crosscare, BITCI, April 2018; MRCI, ICI, May 2018. 


\subsection{IRISH LABOUR MIGRATION POLICY}

It is Irish labour market policy to meet most labour and skills needs from within the domestic and EEA workforce and to educate and upskill the resident population to meet changing demands. Labour migration policy is largely operated through the employment permits system, which is designed to supplement Ireland's skills and labour supply over the short to medium term, by allowing businesses that cannot fill vacancies from within the EEA to recruit from outside the EEA (DBEI, 2018). Labour migration policy is administered, on the basis of the Employment Permits Acts, by the Department of Business, Enterprise and Innovation (DBEI) with input from a new cross-departmental framework, established after the Review of economic migration policy was completed in 2018 by the DBEI.

The above review stated that the employment permits system is largely robust and recommended certain adjustments to ensure responsiveness to changing labour market needs (DBEI, 2018). The system is managed through the operation of occupation lists: the critical skills occupations list, for in-demand highly skilled occupations; and the ineligible occupations list for occupations for which a ready source of labour is deemed to be available within the EEA. Economic migration policy is adjusted through changes to these lists, which are reviewed twice a year to ensure that the system is aligned with current labour market information (see Gusciute et al., 2015). The DBEI website provides information on the process of applying for an employment permit and employer checklists. ${ }^{35}$ Most newly arrived non-EEA workers hold a Stamp 1 registration certificate issued by the Irish Naturalisation and Immigration Service (INIS) and an employment permit issued by the DBEI (McGinnity et al., 2018a).

Future jobs Ireland: 2019 states that in order for Ireland to be able to compete for skilled workers from abroad, it must ensure that the employment permits system operated by the DBEI and the visa system operated by INIS are fair, effective and efficient. The policy statement also emphasises the need to develop skills and improve participation among the population already in Ireland (DBEI, 2019).

\subsubsection{Employment permit system}

Since the enactment of the Employment Permits (Amendment) Act 2014, employment permits fall into the following eight categories: critical skills (CSEP); intra-company transfer (intra-CT); general; contract for services; reactivation; internship; sport and cultural; and exchange agreements. ${ }^{36}$

Comments received from the DBEI, May 2019.

Prior to March 2019, dependants, spouses and partners of critical skills permit holders were required to apply for the dependant/spouse/partner employment permit in order to take up employment. This employment permit is no longer in operation (see Section 2.2.2). 
The type of permit held by a non-EEA national has implications for labour market integration. The most advantageous permit in this regard is the critical skills permit, which is issued to two groups of workers: those who have been offered a job included on the critical skills list, with an annual salary of $€ 30,000$ and over; and those who have an offer of any employment not included on the ineligible list, with an annual salary of $€ 60,000$ and over. The majority of critical skills permits issued fall into the first group. ${ }^{37}$ The aim of the critical skills permit scheme is to encourage such workers to take up permanent residence in the State. ${ }^{38}$ Critical skills employment permits represented the largest proportion (45 per cent) of 11,354 employment permits issued in 2017 (DBEI, 2018). ${ }^{39}$

Critical skills permit holders have immediate family reunification and may reside and work without an employment permit upon completion of the initial two-year critical skills employment permit period. General employment permits may apply for family reunification after 12 months and if other conditions are met (INIS, 2016). General employment permits are issued for a maximum of two years in the first instance and may be renewed upon application for a further three years. After this period, the general employment permit holder may work in the State without an employment permit, with the permission of the Minister for Justice and Equality. (At this point they have accrued enough residence in the State to apply for naturalisation.)

As of March 2019, the spouses and partners of critical skills employment permit holders may access the Irish labour market without needing an employment permit (see below). The spouses and partners of other employment permit holders may not work unless they hold an employment permit in their own right.

All employment permits refer to a specific employer and job; if a non-EEA national wishes to change positions, a new permit application must be made. First time permit holders are expected to remain in the specified position for the duration of their employment permit or for 12 months, whichever period is shorter, before applying to change, except in exceptional circumstances. ${ }^{40}$

$\mathrm{MRCl}$ has expressed the view that the current system of employment permits, particularly the use of employer-specific permits, the ineligible categories of employment list and the salary threshold, prevents labour market mobility, leads

Comments received from the DBEI, May 2019.

DBEI, 'Types of employment permits', available at https://dbei.gov.ie/en/What-We-Do/Workplace-andSkills/Employment-Permits/Permit-Types/.

This was followed by general (38 per cent), intra-CT (eight per cent), dependant/spouse/partner (six per cent), contract for services (one per cent) and sport and cultural (one per cent) employment permits. Reactivation, internship and exchange agreement employment permits each represented less than one per cent of all employment permits issued in 2017.

See https://dbei.gov.ie/en/What-We-Do/Workplace-and-Skills/Employment-Permits/Changing-Employer/. 
to under-employment of non-EU nationals and places migrants at risk of falling into situations of irregularity (for further information, see MRCl, 2015a, 2015b). ${ }^{41,42}$

\subsubsection{Family members}

Family members of non-EEA nationals with an employment permit are generally granted a Stamp 3 residence permission, which precludes the holder from accessing the labour market. If, while resident in Ireland, a family member is offered a job that meets the criteria (for example, one that is not on the ineligible categories of employment list), they may apply for an employment permit in their own right, subject to the approval of the Minister for Justice and Equality. ${ }^{43}$ Once an employment permit is obtained, they can then apply to INIS for a change of residence permission to a Stamp 1 permission, which is granted to employment permit holders. Immediate family members of Irish and EU citizens may access the labour market without an employment permit (INIS, 2016).

Crosscare and $\mathrm{ICl}$ noted the lack of a targeted approach to the integration, including in particular labour market integration, of family members of non-EU nationals in Ireland. ${ }^{44}$ Along with other stakeholders, they pointed to the challenges for family members of non-EU nationals seeking to access the labour market in Ireland (including non-EU nationals in Ireland with resident permits issued for family reasons). ${ }^{45}$

Stakeholders reported that employers may not be willing to go through the process of employment permit applications for family members (Arnold and Quinn, 2016b; $\mathrm{MRCl}, 2015 \mathrm{~b}) .{ }^{46}$ It was reported in the media that confusion around the employment permit system has led many employers to believe that Stamp 3 holders could not apply for work (Pollak, 2018; 2019). Delays in obtaining employment permits for family members were also reported as a barrier to securing employment (Pollak, 2018; 2019). ${ }^{47} \mathrm{ICl}$ and $\mathrm{MRCl}$ highlighted the need to raise awareness among employers, service providers and non-EU nationals about the immigration framework and entitlements in this regard. ${ }^{48}$

Interviews with Crosscare, April 2018; ICI, MRCI, May 2018.

The Reactivation Employment Permit Scheme was introduced in 2014 to assist workers who fall out of the employment permit system through no fault of their own or who are treated badly or exploited in the workplace to work legally again. DBEI, 'Reactivation employment permit', available at https://dbei.gov.ie/en/What-WeDo/Workplace-and-Skills/Employment-Permits/Permit-Types/Reactivation-Employment-Permit/. Comments received from the DBEI, May 2019. Interviews with Crosscare, April 2018; ICl, May 2018. Interviews with Crosscare, April 2018; ICI, MRCI, NCP, May 2018. Interview with Crosscare, April 2018.

INIS, 'Ministers Flanagan and Humphreys announce change to immigration arrangements for spouses and partners of Critical Skills Employment Holders', available at http://www.inis.gov.ie/en/INIS/Pages/press-release-ministersflanagan-and-humphreys-announce-change-to-immigration-arrangements-for-spouses-and-partners-of-criticalskills-employment-permit-holders. Interviews with $\mathrm{ICl}, \mathrm{MRCl}$, May 2018. 
The need to ensure that spouses and partners of critical skills employment permit holders in particular can access the Irish labour market was emphasised in Future jobs: 2019 (DBEl, 2019). ${ }^{49}$ A positive step in this regard was announced in March 2019: spouses and partners of critical skills employment permit holders and researchers on a Hosting Agreement may now access the Irish labour market without the need to obtain an employment permit (DJE and DBEI, 2019). DBEI stated that during 2019 it has undertaken an information drive, in collaboration with DJE, to inform critical skills employment permit holders and businesses of these changes. Information on the change has been made available on the websites of both departments. ${ }^{50}$

The Stamp 3 Association, an association campaigning for access to employment for holders of spousal Stamp 3 residence permission, expressed concern however that this avenue is not also available to family members of general employment permit holders. ${ }^{51}$

\subsection{INTEGRATION IN THE MAINSTREAMED SYSTEM}

OPMI was established in February 2011, assuming the duties of the former Office of the Minister for Integration (McGinnity et al., 2012). It has a cross-departmental mandate to lead and co-ordinate migrant integration policy utilising the framework provided by the current migrant integration strategy. The delivery of integration services rests with individual government departments and agencies (see Figure 2.1). The current strategy notes that the principle of mainstreaming has been established policy since 2008 (DJE, 2017a). The cross-departmental approach was highlighted by OPMI as an important and challenging aspect of ensuring collective implementation of the strategy and integration policy in general. ${ }^{52}$

There are no examples of integration measures in Ireland focusing exclusively on non-EU nationals with a migrant status other than international protection. Many measures that address migrants generally also include Irish and EEA nationals. A number of labour market integration measures and programmes for beneficiaries of international protection and asylum seekers have been established in recent years in the context of increasing inflows of applicants for and beneficiaries of international protection. $\mathrm{ICl}$ observed that some of the measures exclude other migrants from their remit, despite addressing the integration and employment needs that other migrants share with refugees and asylum-seekers. ${ }^{53}$ Gilmartin and Dagg (2018) also recommend that integration services respond to need rather than

See also DBEI, 2018.

Comments received from the DBEI, May 2019.

Stamp 3 Association, 'Welcome change grants real right to work for critical skills spouses', 6 March 2019, available at https://reformstamp3.wixsite.com/home/news/welcome-change-grants-real-right-to-work-for-critical-skillsspouses. 
migrant status. OPMI observed that labour market integration measures should be available to those with a right to access the labour market. ${ }^{54}$

\subsubsection{The current migrant integration strategy}

The migrant integration strategy: A blueprint for the future comprises a framework for government action on migrant integration from 2017 to 2020. Its aim is to enable all migrants to actively participate in Irish communities, workplaces and politics. OPMI observed that an overarching aim of this strategy is to support the equitable provision of public services in order to achieve successful mainstreaming. ${ }^{55}$ The main objective of this strategy is to identify and address barriers to full participation in Irish society (DJE, 2017). As part of this, OPMI noted that service providers must adapt to ensure they can deliver mainstream services equally to all customers. ${ }^{56}$

The current strategy targets EEA and non-EEA nationals, including refugees, economic migrants and people with a legal status to remain in Ireland (DJE, 2017a). Protection applicants generally do not fall within its scope, save where the actions relate to public services that are provided to applicants as a matter of public policy; for example, compulsory education..$^{57}$

The current migrant integration strategy comprises 12 different themes, across which there are 76 actions to be undertaken by government department and agencies, NGOs, political parties and other organisations (see Figure 2.1).

Comments received from OPMI, May 2019.

Interview with OPMI, May 2018.

Interview with OPMI, May 2018.

Comments received from OPMI, May 2019. 
FIGURE 2.1 ACTIONS (N.) OF THE CURRENT MIGRANT INTEGRATION STRATEGY, BY BODIES RESPONSIBLE FOR ITS IMPLEMENTATION

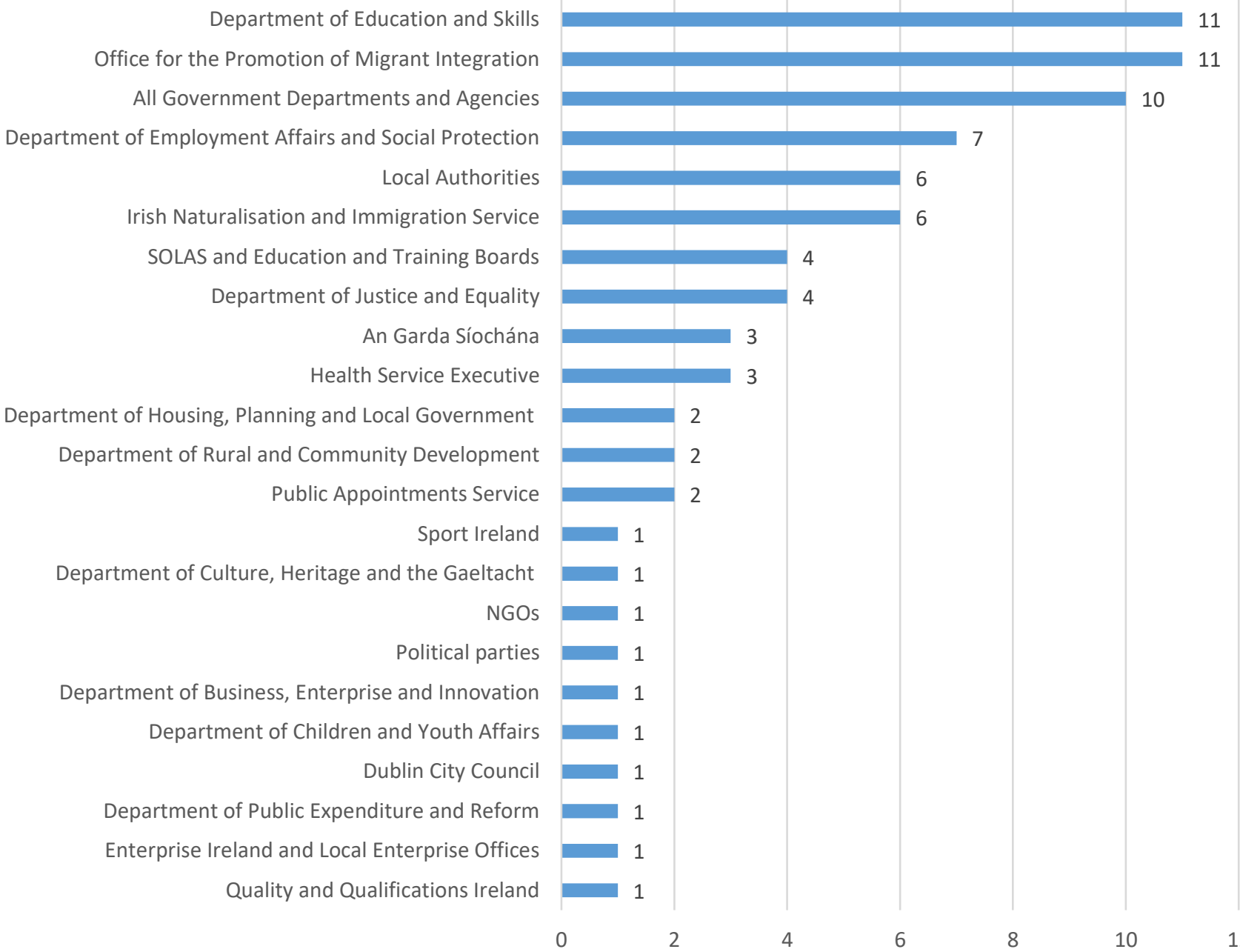

Source: Department of Justice and Equality, 2017a; Consultation with OPMI, May 2019.

The 12 themes under which the 76 actions fall include: general actions; ${ }^{58}$ access to public services; ${ }^{59}$ access to citizenship/long-term residency; ${ }^{60}$ education; ${ }^{61}$ health; ${ }^{62}$

The 'general actions' section consists of actions 1-8 of the Migrant Integration Strategy (2017). The OPMI, as well as government and agency bodies, are responsible for their implementation in the period 2017-2020. The section 'access to public services and social inclusion' consists of actions 15-25. Their implementation is the responsibility of all government departments and agencies, including local authorities in action 17 , in the period of 2017-2020. The section 'Access to citizenship/long-term residency' consists of actions 9-14. Their implementation is the responsibility INIS.

61 'Education' encompasses actions 26-37, and is overseen by the Department of Education and Skills, with the assistance of ETBs (action 32) and SOLAS (action 35). Their timeframes vary; two actions occur annually, five run across the period 2017-2020, while four only run over one year.

62 'Health' consists of actions 48-50, to be implemented by the HSE in the period 2017-2020. 
integration in the community ${ }^{63}$ political participation; ${ }^{64}$ promoting intercultural awareness and combating racism and xenophobia; ${ }^{65}$ volunteering, ${ }^{66}{ }^{6 p o r t},{ }^{67}$ and implementation and follow-up. The theme of employment and pathways to work is the subject of this study (see Chapter 3 ).

There are eight general actions, which focus on: mainstreaming integration issues in strategy statements and the work of government departments; cooperation between departments and NGOs representing migrants; and providing and evaluating (EU) funding integration initiatives.

The migrant integration strategy was informed by a consultation process with NGOs working with migrants and members of the public. $\mathrm{MRCl}$ nevertheless observed a lack of sufficient engagement to date with migrant communities to determine the needs of, and barriers faced by, target groups in devising and implementing the Strategy ${ }^{68}$ The strategy contains an ongoing action to establish local integration networks to reach out to migrant groups and to assist their engagement with government. The establishment of a migrant integration forum by each local authority and an integration network by Dublin City Council are reported as being underway (actions 53 and 54 respectively) (discussed in Section 4.2). Regarding the cross-cutting action applicable to all government departments and agencies on the need to engage regularly with migrant representative groups, OPMI noted that as of January 2019, 16 of 46 government departments and agencies that provided updates reported regular engagement with NGOs representing migrant groups (action 2). ${ }^{69}$

The Migrant Integration Strategy Monitoring and Coordination Committee, which includes representatives of government departments, key public bodies, local authorities and NGOs, was established under the Minister of State at the DJE with special responsibility for equality, immigration and integration (action 74). An (actions 52-53); government departments (actions 51 and 55-57) and Dublin City Council (action 54). All actions occur in the period 2017-2020, except for action 54 and 56, which last a year. 'Political participation' consists of actions 58-60, to be implemented in the period of 2017-2020. The responsible bodies include: the Department of Housing, Planning and Local Government (actions 59-60); local authorities (action 60); and political parties and NGOs (action 58). 'Promoting intercultural awareness and combating racism and xenophobia' encompasses actions 61-71, and involves a wide variety of responsible bodies: local authorities (actions 62 and 64); government departments (actions 61, 65 and 67-71); and An Garda Síochána (actions 63, 66 and 68). All these actions, except for 64, 65 and 70 (which relate to 2017and 2018) are to occur across the 2017-2020 period.

66 The DRCD is tasked with promoting volunteering under action 72 (2017-2020).

67 Sport Ireland/OPMI is responsible for action 73 (2017-2020).

68 Interview with $\mathrm{MRCl}$, May 2018.

69 'Migrant integration strategy: Actions for all departments and agencies', Presentation from OPMI at a meeting of the Monitoring and Co-ordination Committee, held on 31 January 2018, available at http://www.integration.ie/en/ISEC/MISMCC\%20-\%2031\%20Jan\%202018\%20\%20All\%20Presentations.pdf/Files/MISMCC\%20-\%2031\%20Jan\%202018\%20-\%20All\%20Presentations.pdf. 
interim progress report of the current migrant integration strategy is expected to be published during 2019.

Crosscare expressed concern that the implementation of the current strategy is at risk of being fragmented, due to the fact that it is down to each government department and agency responsible for various actions in the strategy to decide the extent of their engagement with it. ${ }^{70}$ In addition, the broad nature of the actions set out in the strategy, as well as the absence of clear targets, was highlighted by stakeholders as a challenge for its implementation. ${ }^{71}$ OPMI noted that it is also proving challenging to raise awareness of the strategy itself among various government departments and agencies responsible for its implementation. ${ }^{72}$

\subsubsection{Data for monitoring integration}

The Monitoring report on integration, published by the Economic and Social Research Institute (ESRI) and the DJE (McGinnity et al., 2018a), presents a range of integration indicators, including those recommended at Zaragoza. The synthesis report for this study found that the Zaragoza indicators were the most commonly used standards to measure the impact of general national integration policies across the EU (EMN, 2019). The outcome of this is a 'bird's eye' view of migrant integration at the national level. Gilmartin and Dagg (2018) recommend supplementing the Zaragoza indicators with context-driven indicators that reflect different experiences across migrant groups and in different geographical areas of the country.

In terms of monitoring the delivery of actions under the migrant integration strategy, OPMI confirmed that limited disaggregated data required for this purpose are available. ${ }^{73}$ However, in line with the commitment set out in the strategy (action 8), the Integration Data Working Group has been established to examine data gaps in relation to integration. In order to inform the activities of the working group, a study was undertaken by the ESRI, on behalf of OPMI, to map the availability of quantitative data relevant to the study of migrant integration in Ireland (Fahey et al., 2019).

\subsection{CHALLENGES TO LABOUR MARKET INTEGRATION}

In 2015, the Migration Integration Policy Index (MIPEX) ranked Ireland 33 out of 38 countries in relation to labour market integration of non-EU nationals (Huddleston et al., 2015). In particular, MIPEX noted that non-EU nationals in Ireland face

Interview with Crosscare, April 2018.

Interviews with Crosscare, BITCl, April 2018; ICl, May 2018.

Interview with OPMI, May 2018.

Consultation with OPMI, July 2018. 
greater obstacles to accessing the labour market and employment in jobs that match their qualifications than they do in other countries examined. BITCI also observed that while migrants in Ireland tend to be very qualified, with the majority holding university or postgraduate degrees, they also tend to be underemployed. ${ }^{74}$ Huddleston et al. (2015) referred to a number of barriers: lack of targeted supports for using and developing skills; lack of access to public sector jobs; and a long and complex procedure for recognition of qualifications.

Research on the experience of migrants in the Irish labour market has identified a number of challenges.

\subsubsection{Under-employment, lack of career progression and low pay}

McGinnity et al. (2018c) found that the 'White EU-East', 'Black Irish' and 'Black non-Irish' groups are particularly disadvantaged in terms of access to jobs at managerial or professional level. Conversely, 'Asian Irish' show a substantial advantage compared to 'White Irish', possibly because many would have arrived in Ireland with a permit for a specific job offer in the high-skilled sectors. ${ }^{75}$

$\mathrm{MRCl}$ found that over 62 per cent of migrant workers surveyed in 2015 had a thirdlevel qualification yet continued to work in jobs well below their skill levels. In addition, 87.4 per cent remained in entry-level jobs, with few progressing to management level despite having worked for the same employer for over two years (MRCl, 2015a). This is in line with earlier research by Barrett and Duffy (2008), which found that immigrants were less likely to be employed in high-level occupations, with nationals of eastern EU Member States in particular reporting the lowest occupational attainment (see also Barrett et al., 2012; Voitchovsky, 2014). The occupational gap and overeducation among immigrants is also an important component of the gap in earnings between immigrants and those born in Ireland (Barrett et al., 2016). ${ }^{76}$ Almost half of participants surveyed by $\mathrm{MRCl}$ earned less than $€ 300$ per week (MRCl, 2015b).

\subsubsection{Discrimination}

Research has found that non-Irish nationals, and particularly individuals of African origin, report higher rates of work-related discrimination than Irish nationals (Kingston et al., 2012; Kingston et al., 2015). McGinnity et al. (2018c) showed that the 'Black non-Irish' group is five times as likely as 'White Irish' to report experiencing discrimination seeking work and 2.7 times as likely to experience

$74 \quad$ Interview with BITCl, April 2018.

75 After five years of residency, many Asian individuals became eligible for citizenship. McGinnity et al. (2018) in the monitoring report on integration (2018a), show a high proportion of Asian nationals among the naturalised citizens from 2013 onwards.

76 EPIC also observed that migrants in Ireland tend to be very qualified and that the majority have university or postgraduate degrees, but also tend to be underemployed. Interview with BITCI, April 2018. 
discrimination in the workplace. McGinnity et al. (2018c) found that the "White non-EU' group shows no difference in employment rates or occupational position compared to 'White Irish', but are more likely to experience work-related discrimination. The 'Asian non-Irish' group does not differ from 'White Irish' in terms of employment rates or discrimination seeking work, but does report higher rates of discrimination in the workplace and is somewhat less likely to be in the top jobs (McGinnity et al., 2018c). ${ }^{77}$

\subsubsection{Other barriers to accessing employment}

Other barriers include: inadequate English language skills; poor links or contacts to facilitate access to the labour market; lack of recognition of qualifications; and potential need to up-skill (O'Connell, 2018; Gusciute et al., 2016). MRCl observed exploitation disproportionately affects migrant workers (MRCI, 2015a).

Similar challenges were reported by policymakers tasked with supporting migrants across the EU, in particular the accreditation of job qualifications and skills assessment, discrimination within recruitment processes and managing varying levels of language skills in integration measures. These difficulties are particularly pronounced when dealing with migrant women or vulnerable groups (EMN, 2019).

The wider housing crisis in Ireland is also seen as posing a challenge to implementing integration policy. The shortage of housing may delay migrants' access to integration supports and thus their integration into Irish society in general and the labour market in particular. ${ }^{78}$

77 The analysis in McGinnity et al. (2018c) is based on pooled data from the special modules of the labour force survey in 2004, 2010 and 2014. This data provide information on labour market outcomes and the experience of discrimination. 



\section{CHAPTER 3}

\section{Labour market integration strategy}

\section{$3.1 \quad$ INTRODUCTION}

The migrant integration strategy: A blueprint for the future states that 'the stability offered by employment, and the possibility that it offers to engage with others in the community, can enhance the integration process'. The strategy explicitly addresses the labour market integration of migrants under the heading 'Employment and pathways to work'; this section focuses on those actions. The government departments and agencies responsible for implementing the relevant actions are outlined and developments are discussed.

It should be noted that other important local-level programmes and initiatives for community development in Ireland also impact significantly on migrant integration, such as the Social Inclusion Community Activation Programme (SICAP); however, a detailed discussion of these is outside the scope of the current study.

\subsection{INSTITUTIONAL FRAMEWORK FOR LABOUR MARKET INTEGRATION UNDER THE MIGRANT INTEGRATION STRATEGY}

The key government departments and agencies responsible for implementing the actions under the employment section of the migrant integration strategy are: Central Statistics Office (CSO) (action 38); the Further Education and Training Authority (SOLAS) and Education and Training Boards Ireland (ETBI) (actions 39 and 40); Department of Employment Affairs and Social Protection (DEASP) (actions 41 and 42); Quality and Qualifications Ireland (QQI) (action 43); the Public Appointments Service (PAS) (actions 44 and 46); Department of Public Expenditure and Reform (DPER) (action 45); and Enterprise Ireland, as well as local enterprise offices (LEOs) (action 47). Figure 3.1 shows the institutional framework for labour market integration, as indicated by the strategy. 
FIGURE 3.1 ORGANOGRAM OF THE INSTITUTIONAL FRAMEWORK FOR LABOUR MARKET INTEGRATION AS INDICATED BY THE MIGRANT INTEGRATION STRATEGY (2017-2020)

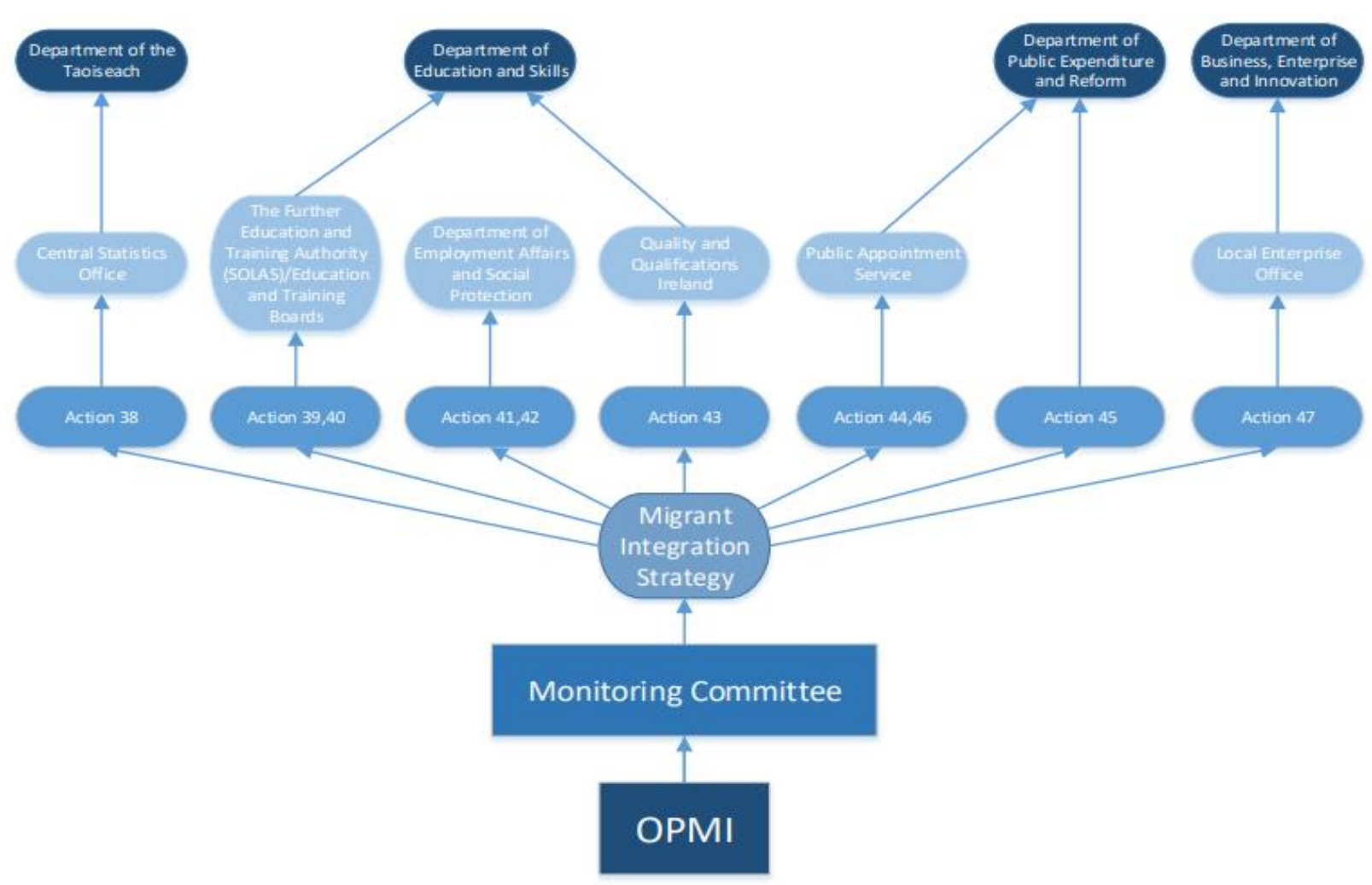

\subsection{LABOUR MARKET INTEGRATION ACTIONS UNDER THE MIGRANT INTEGRATION STRATEGY}

Ten actions are included under the heading 'Employment and pathways to work'. The overall objective of the actions is to enable migrants to participate in economic life, namely in employment and self-employment, as well as to support them in accessing and navigating relevant employment supports provided by public services. Equipping migrants with sufficient language skills to enable them to participate in the wider society is also among the objectives of the labour market integration measures (DJE, 2017a). Table 3.1 summarises the status of the actions, as of April 2019. 
TABLE 3.1 EMPLOYMENT AND PATHWAYS TO WORK: STATUS OF ACTIONS, APRIL 2019

\begin{tabular}{|c|c|c|c|}
\hline Action & Brief description & Responsible body & Status April 2019 \\
\hline Action 38 & $\begin{array}{l}\text { Continue publishing disaggregated data on } \\
\text { unemployment. }\end{array}$ & $\mathrm{CSO}$ & On track \\
\hline Action 39 & $\begin{array}{l}\text { Ensure further education and training } \\
\text { programmes meet the specific needs of } \\
\text { migrants. }\end{array}$ & SOLAS and ETBs & $\begin{array}{l}\text { Minor problems or } \\
\text { delays }\end{array}$ \\
\hline Action 40 & $\begin{array}{l}\text { Ensure programmes specifically catering for } \\
\text { unemployed migrants whose language skills } \\
\text { require development contain a language } \\
\text { component. }\end{array}$ & SOLAS and ETBs & $\begin{array}{l}\text { Minor problems or } \\
\text { delays }\end{array}$ \\
\hline Action 41 & $\begin{array}{l}\text { Ensure appropriate levels of engagement } \\
\text { with migrants registered as jobseekers. }\end{array}$ & DEASP & On track \\
\hline Action 42 & $\begin{array}{l}\text { Undertake an analysis to assess the extent } \\
\text { to which the level of joblessness among } \\
\text { jobseekers of African origin exceeds that of } \\
\text { other groups and determine actions to } \\
\text { address this. }\end{array}$ & DEASP & Complete \\
\hline Action 43 & $\begin{array}{l}\text { Promote the QQI system for recognition of } \\
\text { vocational skills accredited in other } \\
\text { countries more widely. }\end{array}$ & QQI & $\begin{array}{l}\text { Minor problems or } \\
\text { delays }\end{array}$ \\
\hline Action 44 & $\begin{array}{l}\text { Proactive outreach and support measures } \\
\text { by all public sector employers to increase } \\
\text { the number of persons from an immigrant } \\
\text { background working at all levels in the civil } \\
\text { service and wider public service. }\end{array}$ & PAS & On track \\
\hline Action 45 & $\begin{array}{l}\text { Ensure one per cent of the public workforce } \\
\text { is from an ethnic minority background. }\end{array}$ & DPER & On track \\
\hline Action 46 & $\begin{array}{l}\text { Undertake further activities to raise } \\
\text { awareness of state board opportunities } \\
\text { among groups under-represented on state } \\
\text { boards. }\end{array}$ & PAS & On track \\
\hline Action 47 & $\begin{array}{l}\text { Continue to undertake targeted initiatives } \\
\text { to engage with prospective migrant } \\
\text { entrepreneurs in line with local need. }\end{array}$ & $\begin{array}{l}\text { Enterprise } \\
\text { Ireland/LEOs }\end{array}$ & On track \\
\hline
\end{tabular}

Source: $\quad$ OPMI, April 2019.

\subsubsection{Education, training and English for speakers of other languages (actions 39,} 40)

The Education and Training Boards Act 2013 (2013 Act) provides for the establishment of education and training boards (ETBs) to provide education and training, including for the purpose of employment. ${ }^{79}$ The principal objective of Education and Training Boards Ireland (ETBI), the national representative association for ETBs, is to promote the development of education, training and

79 Its predecessor, the Vocational Education Committee, was dissolved 1 July 2013. The 2013 Act also provided that ETBI would represent the ETBs. 
youth work in Ireland. ${ }^{80}$ The 2013 Act established SOLAS to manage, co-ordinate and support the delivery of an integrated further education and training strategy by the 16 ETBs around the country.

ETB programmes can be accessed by all non-EU nationals, refugees and, in some cases, asylum seekers, free of charge, by self-referral or by referral from another organisation, such as the New Communities Partnership (NCP). ${ }^{81}$ Residence permission and associated rules regarding employment and unemployment may impact upon access to some programmes (for example Youthreach). ${ }^{82}$ ETBI noted that they may also respond to government department or state agency requests by introducing a programme focused on the needs of the particular group of migrants. ${ }^{83}$

\section{Action 39: Education and training programmes}

Under action 39, SOLAS and the ETBs are responsible for ensuring that further education and training courses meet the specific needs of migrants; for example, language acquisition, knowledge of the Irish working environment, interview skills and CV preparation. The migrant integration strategy states that these courses can be provided directly as part of principal courses or through part-time modular provision parallel to learners' participation in principal courses.

While the programmes available to migrants were in place prior to the migrant integration strategy, ETBI expressed their view that programmes have been enhanced and improved since the publication of the strategy. ${ }^{84}$ Key activities specific to labour market integration of migrants provided by ETBs include digital literacy and numeracy, and English for speakers of other languages (ESOL) language support, interview skills and CV preparation guidance, and traineeships and apprenticeships (including in the private sector). ${ }^{85}$

ETBI stated that there are opportunities for the provision of workplace education for migrants through the Skills for Work programme, a national initiative delivered by ETBs across the country aimed at providing training opportunities to help employees deal with the basic skills demands of the workplace. Skills for Work is a programme for people in full- or part-time employment who have low levels of education or certification. Upskilling and certification programmes are offered free of charge, generally in the workplace. ${ }^{86}$

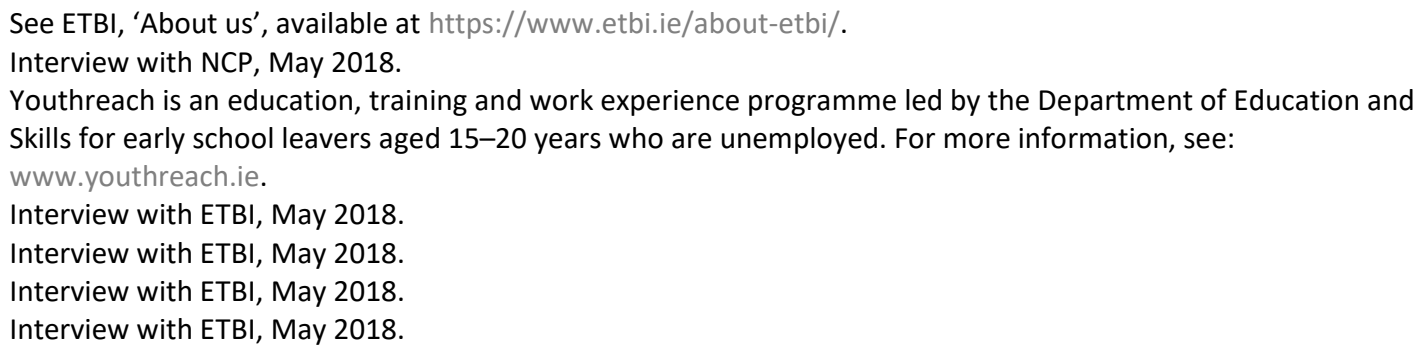




\section{Key challenges: Education and training}

ETBI observed that there are challenges in addressing the further education and training needs of migrants; for example, resources available and ensuring relevant courses are available at the required level. ${ }^{87}$

NCP observed that research is needed to understand the specific training needs of migrants in Ireland. ${ }^{88} \mathrm{ICl}$ noted that provision of orientation in the Irish working environment is an important but overlooked element of the integration process. ${ }^{89}$ $\mathrm{NCP}, \mathrm{MRCl}$, Business in the Community Ireland (BITCl) noted that another important aspect of labour market activation programmes is confidence-building among participants. ${ }^{90}$ The need for effective programmes focused on the provision of fundamental skills to assist unemployed persons re-enter the labour market was also highlighted by the Organisation for Economic Co-operation and Development (OECD, 2018a).

BITCl welcomed the migrant integration strategy's focus on meeting the employment needs of migrants in further education and training. It highlighted the need to consult with organisations that have expertise in working with migrant communities and assisting migrants to access the labour market, including $\mathrm{BITCl}$ itself, in tailoring programmes to the needs of migrants. ${ }^{91}$ OPMI noted that action 39 was designated as having 'minor problems or delays'. ${ }^{92}$ 
Employment for People from Immigrant Communities (EPIC) is a programme run by Business in the Community Ireland (BITCI). ${ }^{93}$ The EPIC programme supports immigrants in Ireland to become financially independent and more socially integrated by entering employment or further education and training. EPIC's budget was approximately $€ 1.9$ million in 2018. EPIC is partly funded by the European Social Fund (ESF) PEIL 'Integration and Employment of Migrants' (see Chapter 4) and the Department of Justice and Equality (DJE)..$^{94}$

EPIC works with businesses to provide specialised supports to jobseekers. It runs a sixweek group training programme 14 times per year, and provides individual support to programme participants. The training programme focuses on $\mathrm{CV}$ and cover letter preparation, ${ }^{95}$ the interview process, ${ }^{96}$ and identifying employment and education opportunities. ${ }^{97}$ Information is provided on services, rights and entitlements, and, occasionally, on culture in Ireland. ${ }^{98}$ Each participant is assigned a career counsellor who works with them individually, and with whom a career plan is developed. ${ }^{99}$ EPIC is integrated within the business community, which enables participants to learn about organisations that participate in the programme and then apply for jobs as they open up. ${ }^{100,101,102}$

The programme covers the Dublin area. EU and non-EU nationals with Stamp 4 residence permission may access EPIC. Clients must also have adequate English language competency, as language support is not part of the programme. ${ }^{103}$ Migrants can access EPIC by submitting an application, but BITCI noted that there is generally a two-month waiting list. ${ }^{104} \mathrm{EPIC}$ also sends information to organisations that work with migrants and encourages referrals from Intreo. ${ }^{105} \mathrm{BITCl}$ observed that building relationships with

$\mathrm{BITCl}$ is a network for sustainable and responsible business in Ireland.

$\mathrm{BITCl}$, 'Are you a jobseeker?', www.bitc.ie.

BT, a telecoms company, provides two days of IT skills training to clients. Interview with BITCI, April 2018.

$\mathrm{Cpl}$, a recruitment agency, provides interview training to clients. Enterprise Rent-A-Car, a car rental company, also run interview skills workshops. Interview with BITCI, April 2018.

Accenture, a professional services company, provides CV workshops and motivational talks for clients.

Outside organisations may provide this information, such as Cáirde, an organisation that works towards improving ethnic minority health. Cáirde provides information to participants on healthcare in Ireland. Interview with $\mathrm{BITCl}$, April 2018. Interview with BITCl, April 2018.

KPMG, a professional services company, provide a mentorship service for EPIC clients who wish to work in the financial sector. Interview with BITCl, April 2018.

EPIC also arrange visits for participants to companies, during which companies explain their work and employees talk about their pathway to employment. Interview with BITCI, April 2018.

Business in the Community, 'Are you a jobseeker?', available at https://www.bitc.ie/business-actionprogrammes/business-action-on-employment/are-you-a-jobseeker/. Interview with $\mathrm{BITCl}$, April 2018.

Intreo is a single point of contact for all employment and income supports. Designed to provide a more streamlined approach, Intreo offers practical, tailored employment services and supports for jobseekers and employers. For more information, see https://www.welfare.ie/en/pages/intreo_home.aspx. The employment and income support service of the DEASP also refer people, but awareness of EPIC varies across the Intreo offices. BITCI noted that they would like to improve information dissemination to all Intreo offices. 
individual case officers over time is the most effective means of encouraging referrals from Intreo offices. ${ }^{106}$

Every year, the programme works with up to 300 people, including approximately 224 new clients. ${ }^{107}$ Since its foundation, EPIC has worked with 3,000 people from 101 countries. Over two-thirds (68 per cent) of their clients have found employment, entered training or are volunteering. ${ }^{108}$ Stakeholders interviewed for this study identified EPIC as an example of good practice ${ }^{109}$ and a model to build upon. ${ }^{110}$ OPMI noted that there are a number of relevant projects funded under AMIF and the ESF (see 2.1), but no organisation other than EPIC has the same access to the corporate sector. ${ }^{111}$

Action 40: Provision of English for speakers of other languages (ESOL)

SOLAS and the ETBs are also responsible for implementing action 40, which provides that education or training programmes catering for unemployed migrants, whose language skills require development, will contain a language component. In addition, SOLAS and the ETBs are responsible for reviewing the provision of ESOL classes to cater for the language needs of adults from ethnic minority backgrounds, following the development of ESOL policy guidelines (action 32). ETBI noted that due to the considerable demand among migrant communities for English language skills, the provision of English language programmes is considered a high priority in the services they provide, stating that all ETBs provide English language provision for migrants across a range of programmes. ${ }^{112}$

The Further education and training strategy 2014-2019, developed by SOLAS, noted that ESOL classes are provided to meet the needs of learners with a highlevel of education and professional and skilled backgrounds. However, this strategy acknowledges that a significant number of learners have had a low level of formal education in their country of origin and can therefore lack basic literacy skills (SOLAS, 2014). The current adult literacy and numeracy strategy, which forms part of the above further education and training strategy, includes a commitment to provide a clear policy for ESOL provision, giving 'priority to low-skilled and unemployed migrants' (SOLAS, 2014).

In March 2018, ETBI and SOLAS published 24 recommendations for good practice in English language provision and language assessment for low-skilled and unemployed migrants (Kett, 2018). The recommendations in the report are to be

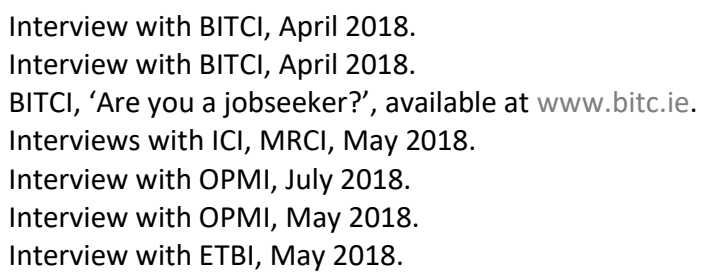


prioritised by a National Advisory Committee; who will sit on this Committee was not specified. Kett (2018) found that the provision of ESOL programmes in Ireland developed in the absence of a national strategy. Individual ETBs may develop programmes in response to demand at local level and some have developed their own internal protocols. ${ }^{113}$ The need for a national framework for publicly funded ESOL provision, and for funding for ESOL to be prioritised, was therefore reiterated (Kett, 2018). The report highlighted existing good practice in ESOL and a strong commitment across ETBs to provide flexible and responsive learning options to migrants whose first language is not English. ETBI noted that continued work among ETBs is important in assisting non-English speaking migrants to develop the language skills needed to participate fully in Irish life. ${ }^{114}$

The ETBI stated that their overall objective is to increase migrants' participation in their services, particularly literacy, ESOL and numeracy, so that they may gain a 'foothold' in the Irish economy. ${ }^{115}$ ETBI noted that they are working to ensure there is a greater degree of consistency and coherence across the country in relation to the programmes provided. ${ }^{116}$

Stakeholders interviewed for the present study observed the lack of a structured framework in which tailored English language programmes are provided to non-EU nationals. ${ }^{117} \mathrm{BITCl}$ also emphasised the need for a government-funded strategy to provide for structured and accessible English language classes, having observed a lack of awareness among government departments, service providers and migrants themselves about the relevant services providing English language classes in Ireland. ${ }^{118}$ Similarly, $\mathrm{ICl}$ and $\mathrm{MRCl}$ recommend that tailored language programmes are put in place that cater for different employment needs, focusing on entry, participation and progression in the labour market (MRCI, 2015b). ${ }^{119}$

In April 2019, OPMI advised that action 40 was designated as having 'minor problems or delays'. ${ }^{120}$ The forecast number of beneficiaries for ESOL in 2018 was 14,749 (SOLAS, 2018), up from 13,232 forecast for 2016. ETBI reported that in 2018, 10,399 individuals undertook an ESOL course and this represented an increase on 2017. ${ }^{121}$ During 2017 and up to (and including) October 2018, a total

Interview with ETBI, May 2018.

Correspondence with ETBI, July 2018.

Interview with ETBI, May 2018.

Interview with ETBI, April 2018.

Interviews with Crosscare, BITCI, April 2018; ICI, MRCI, NCP, May 2018.

Interview with $\mathrm{BITCl}$, April 2018.

Interview with ICl, May 2018.

Comments received from OPMI, April 2019.

Comments received from ETBI, June 2019. 
of 4,675 ESOL beneficiaries progressed to further and/or higher education and training, at the same or higher level, and 309 progressed to employment. ${ }^{122}$

\section{Key challenges: Accessing English language supports}

Difficulties in obtaining a personal public service number (PPSN, the Irish social security number), which is required for enrolment, was identified as a recurring challenge to accessing ETBI services. ETBI noted that the decision as to whether or not to accept a student without a PPSN is at the discretion of each individual ETB. ${ }^{123}$

NCP noted that they regularly encourage clients to access ETBs for language and further education supports, as part of their training and information sessions. However, NCP also observed that migrant participants can find language acquisition programmes and skills courses to be intimidating. NCP also observed that some migrant participants were unaware of services available, while others expressed the view that the programmes available did not meet their specific needs. ${ }^{124}$

\subsubsection{Recognition of qualifications (action 43)}

Action 43 of the migrant integration strategy states that the Quality and Qualifications Ireland (QQI) system for recognising vocational skills accredited in other countries is to be promoted during the period 2017-2020. QQI acts as the Irish national academic recognition information centre (NARIC), and provides advice on the recognition of a foreign qualification by comparing it, where possible, to a major award type and level on the Irish National Framework of Qualifications (NFQ). Generic comparability statements are available online on more than 1,100 foreign academic qualifications. ${ }^{125}$

$\mathrm{BITCl}, \mathrm{ICl}, \mathrm{MRCl}$ and NCP welcomed the specific action dedicated to promoting the $\mathrm{QQ}$ system; however, all these bodies noted that more efforts are needed, including that provision needs to be made for recognising qualifications by Irish professional bodies, ${ }^{126}$ and increased promotion of the QQI to non-EU nationals and service providers. ${ }^{127} \mathrm{MRCl}$ recommended that a dedicated structure is

Comments received from OPMI, April 2019.

The Legal Services Support Unit of the ETBI has clarified that Section 262(1) of the Social Welfare Act 2005 defines a transaction with a specified body to include an application with an ETBI (Correspondence with ETBI, May 2019) and is therefore entitled to request PPSNs from service users. ETBI also noted it is required to record PPSNs for reporting to funders, including the ESF and the government. However, ETBI observed that DEASP may not be aware that students are required to have a PPSN to access ETBI courses and training. ETBI reported that ETBI staff may need to assist learners to obtain their PPSN by providing them with a letter of support to DEASP. The ETBI stated that, although it may enrol students while they apply for their PPSN, delays in obtaining PPSNs mean ETBs may not be in a position to record those students as part of their student cohort or report on progress made. Interview with NCP, May 2018.

Comments received from OPMI, April 2019.

Interview with $\mathrm{BITCl}$, April 2018.

Interview with NCP, May 2018. 
established to bring together educational authorities, professional bodies and employers for the recognition of qualifications in Ireland (MRCI, 2015b).

In April 2019, OPMI advised that action 43 was designated as having 'minor problems or delays' : QQI has focused on increasing awareness of the service. ${ }^{128}$

\section{Key challenges: Beyond QQI}

Recognition of non-EU nationals' qualifications was raised by stakeholders as a challenge to implementing labour market integration policies. ${ }^{129}$ While many nonEU nationals may have their qualifications recognised through QQI, soft barriers have nevertheless been reported, including situations where employers are not familiar with the university from which a degree was obtained (Gusciute et al., 2016). Due to the lack of recognition of migrants' skills and qualifications in practice, migrants may experience under-employment in low-paid and poorly regulated sectors, hindering their labour market integration ( $\mathrm{MRCl}, 2015 \mathrm{~b}$ ). Stakeholders have underlined the need for courses that aim to bring qualifications and skills to the required standard in Ireland, in order to ensure transferability of skills and qualifications (The Integration Centre, 2012). ${ }^{130}$

The need for appropriate awarding and recognition of learning outcomes was also raised by ETBI in relation to the provision of ESOL programmes. All ETBs provide accreditation through QQI. ${ }^{131}$ However, SOLAS and ETBI highlighted that there is little evidence that QQI language awards have recognition outside of ETBs, when compared with international awards such as those offered by the University of Cambridge. The majority of ETBs support the introduction of new awards clearly aligned to the Common European Framework of Reference proficiency bands (Kett, 2018).

The migrant integration strategy includes an action to extend the use of the Common European Framework of Reference for languages (CEFR) (action 35). The CEFR is used on an ad-hoc basis in a number of ETBs in Ireland (Kett, 2018). ${ }^{132}$ ETBI reported that awards for QQI levels 1-4 are currently being reviewed and that broad standards will be developed to guide the planning of future programmes. CEFR will inform the ESOL part of this review. ${ }^{133}$ In parallel, QQI is currently researching the potential linkages, if any, between the CEFR and the NFQ, with the objective of better supporting providers in the development and delivery of language programmes. ${ }^{134}$

Comments received from OPMI, April 2019.

Interviews with Crosscare, BITCl, April 2018; ICI, MRCI, NCP, May 2018.

Interview with ICl, May 2018.

Interview with ETBI, May 2018.

In the ETBI/SOLAS report on good practices in ESOL provision, 15 ETBs reported referencing assessment outcomes against the CEFR.

Correspondence with ETBI, May 2019.

Correspondence with ETBI, July 2018. 


\subsubsection{Seeking employment and self-employment (actions $41-42$ and 44-47).}

\section{Actions 41-42: Seeking employment}

In accordance with the migrant integration strategy, DEASP is responsible for ensuring appropriate levels of engagement with migrants registered as jobseekers (action 41). DEASP reported that document translation and language interpretation services are provided to facilitate engagement, and are available on request or where it is apparent that the customer's interaction with the Department could be improved with such services. DEASP stated that posters in a number of languages are displayed in Intreo offices, indicating availability of language interpretation services. ${ }^{135}$ DEASP reported that all clients registered as jobseekers avail of an activation process and are given a personalised one-to-one service provided by a case officer. They complete a 'personal progression plan', where their specific education, training and development needs are identified, in order to enable them to access the labour market. A walk-in service is also available to unemployed people not on the live register. In April 2019, OPMI advised that this action was 'on track'. ${ }^{136}$

DEASP is also responsible for undertaking an analysis to assess the extent to which the level of joblessness among jobseekers of African origin exceeds that of other groups and to determine what action, if any, is required to address any evidence that this group faces higher barriers to accessing employment (action 42). DEASP published the study in December 2018 and the action is now complete. ${ }^{137}$ Using administrative data from the Jobseekers Longitudinal Dataset (JLD), DEASP showed that African jobseekers have the lowest employment rate among all nationality groups after 12 months. Africans also show the highest rates of leaving the Live Register to pursue education or training. The conclusions point to the potential (negative) impact of time spent out of the labour market as an asylum applicant and the need for further research in this area. It is currently not known what overlap exists between jobseekers and previous asylum applicants (DEASP, 2018).

DEASP reported that, given the labour market improvements seen in recent years during the lifecycle of Pathways to Work 2016-2020, it is preparing to develop a new activation framework, which would include taking a proactive activation approach to people who are not registered as unemployed. ${ }^{138}$

\section{Key challenges}

Research by Crosscare (2018) showed that migrant customers with language support needs may not access, or even be aware of, appropriate interpreter services in DEASP services, including Intreo offices. Instead, they may continue to use informal networks, NGOs or private profit-making networks to access

Comments received from DEASP, June 2019.

Comments received from OPMI, April 2019.

Comments received from OPMI, April 2019.

Comments received from DEASP, June 2019. 
interpreters, often at a cost and with risk to confidentiality and reliability. The research found that migrant NGOs may also be unaware of the availability of interpreters in accessing DEASP services. DEASP reported that it has since increased efforts to encourage frontline staff to avail of document translation and language interpretation services, which are available at the customer's request or where it is apparent that the service is needed. ${ }^{139}$

\section{Actions 44-46: Employment in the public sector}

Actions 44 to 46 refer to migrant participation in the public service. The Public Appointments Service (PAS) is responsible for increasing the number of persons from an immigrant background who consider a career in the civil and public service, by promoting opportunities through outreach and support measures (action 44). ${ }^{140}$ This action has regard to the fact that in most cases, civil service employment is not open to non-EEA nationals (DJE, 2017a).

A marketing strategy has been developed by PAS to establish brand recognition and to enhance the quality and diversity of candidate pools, including migrants. ${ }^{141}$ PAS reported that following market research on specific migrant communities, they revised their approach to outreach. PAS now uses social media to target community groups (ethnic, cultural, Polish language) and partnerships. PAS participates in the Institute of Guidance Counsellors Conference, Career Zoo (targeting Brazilian, African, South American and Filipino nationals), new Irish citizenship ceremonies, Intreo careers fairs and Jobcare. PAS also advertises in relevant cultural publications. The website publicjobs.ie has also been revised to address potential issues for migrants; for example, the level of English language competence required.

The measure of success foreseen under this action is a 20 per cent increase in new visitors to publicjobs.ie (including five per cent from the migrant community). The action was noted to be 'on track' by OPMI in April 2019. ${ }^{142}$

PAS is responsible for undertaking activities to raise awareness of state board opportunities among groups who are under-represented in society (action 46). In this regard, PAS reported that they have run radio advertising campaigns and social media campaigns (primarily via Twitter). Success under this action is measured as a 20 per cent increase in new visitors to stateboards.ie (including two per cent from the migrant community). Again, this action was noted to be 'on track' by OPMI. ${ }^{143}$

\footnotetext{
139 Comments received from DEASP, June 2019.

140 The PAS is the leading provider of recruitment, assessment and selection services for civil services in Ireland. See: https://www. publicjobs.ie/en/. 
Action 45 is assigned to the DPER. It sets a target of one per cent of the public workforce being from an ethnic minority background. This is to be achieved by: putting in place arrangements to identify the number of civil servants from ethnic minorities; broadening outreach in schools and ethnic communities to provide information about the civil service and career opportunities; and reviewing the composition of the applicant pool to inform the development of targeted measures to encourage applications from areas of society that are underrepresented (action 45). Under this measure, success is defined as four per cent of applications being from migrant communities. OPMI described this action as being 'on track'. ${ }^{144}$

\section{Key challenges}

In collaboration with Trinity College Dublin's Innovation Academy, PAS has carried out projects to inform outreach, specifically for people of a Polish and Asian background who are Irish/EEA citizens, and to increase awareness among these communities about employment in the public sector. ${ }^{145}$ Findings from the research indicate that a large number of Irish/EEA citizens with a migrant background are not aware of their eligibility for public sector jobs in Ireland. ${ }^{146}$ NCP also observed that migrants do not know how to access the public sector or whether they are eligible to do so. ${ }^{147}$ While the majority of public sector jobs are limited to EEA citizens, PAS noted that increased outreach may additionally ensure that non-EU nationals who may later acquire Irish/EEA citizenship are more aware of opportunities in the public sector. ${ }^{148}$

\section{Action 47: Self-employment}

Pursuant to the migrant integration strategy, LEOs are responsible for undertaking initiatives to engage with prospective migrant entrepreneurs in line with local need (action 47). ${ }^{149}$ The centre of excellence in Enterprise Ireland will promote best practice activities in this area among all LEOs nationally. OPMI reported that the action was 'on track' in April 2019, with 51 per cent of local authorities reporting that their LEO had undertaken targeted initiatives or had proposals under consideration to address the action. ${ }^{150} \mathrm{ICl}$ and $\mathrm{MRCl}$ observed that no data are available from LEOs on migrant entrepreneurship or migrant access to their services. ${ }^{151}$

Comments received from OPMI, April 2019.

See: https://www. publicjobs.ie/en/diversity-and-inclusion.

Interview with PAS, May 2018.

Interview with NCP, May 2018.

Interview with PAS, May 2018.

LEOs provide advice, information and support to anyone hoping to start up or grow a business. There are 31 teams across the local authority network in Ireland. LEOs offer a wide range of experience, skills and services. See: LEO,

'How we can help you?', available at www.localenterprise.ie. 
Funding was made available under the gender equality activity of the European Social Fund's (ESF) Programme for Employability, Inclusion and Learning 2014-2020 (PEIL). One project entitled Building Better Futures - Building Social Enterprise with Migrant Women Entrepreneurs specifically targets migrant women and women from an immigrant background. $\mathrm{MRCl}$ received $€ 279,092$ funding for this project. ${ }^{152}$ Training was offered to migrant women entrepreneurs who have previous business experience and a start-up idea. ${ }^{153}$ Participation was voluntary and free of charge. Applicants in receipt of Jobseekers' Allowance or Jobseekers' Benefit were ineligible. ${ }^{154} \mathrm{MRCl}$ ran the entrepreneurship training project in partnership with the DCU Ryan Academy for Entrepreneurship. A total of 25 participants undertook the nine-week entrepreneurship training project. ${ }^{155}$

A second strand of the project seeks to support the development of a new model of homecare, as well as an initial pilot of a worker-owned social enterprise that can deliver quality care and quality jobs. The Social Enterprise Development Company (SEDCo) ${ }^{156}$ is partner for this social enterprise project. During the initial development stage of the social enterprise, $\mathrm{MRCl}$ worked with seven migrant women to develop an organisational model of homecare. ${ }^{157}$

While these projects are not directly linked to national programmes or to the migrant integration strategy, they do support migrant women to engage in self-employment, thus reflecting the objectives set out in action 47 of the strategy in undertaking an initiative to engage migrant entrepreneurs. $\mathrm{MRCl}$ noted that the project generates long-lasting relationships and increases confidence. ${ }^{158} \mathrm{OPMI}$ also described this project as positive, in particular because of the creation of potential links between local employers and local authorities through the training. OPMI is interested in the outcome of this study, specifically whether the training results in measurable access to the labour market. ${ }^{159}$ $\mathrm{MRCl}$ also observed that the absence of research, evaluations, data or documents on good practice available in the area of entrepreneurial programmes poses challenges for those setting up entrepreneurial programmes for migrant women. ${ }^{160}$

\footnotetext{
152 See http://eufunding.justice.ie/en/eufunding/pages/integrationemployment.

$153 \mathrm{MRCl}$, 'Building better futures: Migrant women's entrepreneurship training', available at www. mrci.ie.

$154 \quad$ Interview with $\mathrm{MRCl}$, May 2018.

DCU Ryan Academy is a not-for-profit partnership between Dublin City University and the Ryan family (of Ryanair). Social enterprise charity. See: SEDCo, 'About', available at http://sedco.ie/about-2/. Interview with $\mathrm{MRCl}, 2018$. Comments received from MRCI, May 2019.

Interview with $\mathrm{MRCl}$, May 2018.

Interview with OPMI, May 2018.

Interview with $\mathrm{MRCl}$, May 2018.
} 


\section{CHAPTER 4}

\section{Local and private involvement}

\section{$4.1 \quad$ INTRODUCTION}

This chapter looks at local implementation of measures that specifically target the labour market integration of migrants. Various initiatives and projects take place at local level/within the community, often as part of social inclusion activities, for example those funded under the Social Inclusion and Community Activation Programme (SICAP). These impact locally on migrant integration but are not reported on under the national migrant integration strategy. National funding administered by the Office for the Promotion of Migrant Integration (OPMI) to support specific labour market integration initiatives is described below, along with some examples of specific measures that have been funded. It is important to note that funding is also available from other government departments that support labour market integration, such as the Department of Education and Skills (DES), the Department of Rural and Community Development (DRCD) and the Department of Employment Affairs and Social Protection (DEASP).

A number of actions in the migrant integration strategy refer to a link between national policy (the strategy itself) and local or community initiatives. Action 2 states that government departments and agencies will ensure regular engagement with non-governmental organisations (NGOs) representing migrant groups (Department of Justice and Equality, 2017a). OPMI reported that by January 2019, out of 46 departments and agencies, 16 provided updates reporting regular engagement with NGOs representing migrant groups. ${ }^{161}$

Action 4 states that decisions on grants to community and sports organisations will include a criterion on promoting integration activities. OPMI reported that by January 2019, of the 18 departments and agencies who reported providing grants to community and sports organisations, six stated that those grants included such a criterion. ${ }^{162}$

Action 5 states that periodic evaluations measuring the outcomes of funding initiatives will be carried out. An independent interim evaluation of Ireland's national programme under the EU Asylum, Migration and Integration Fund (AMIF) 2014-2020 was carried out in December 2017. ${ }^{163}$ OPMI reported that interim and 
final reports from projects funded were also provided (see discussion in the remainder of Section 4.4). ${ }^{164}$

Action 6 states that OPMI will make funding available to national and local groups to carry out integration activities with a particular emphasis on regional and local projects. The National Funding to Promote the Integration of Immigrants was launched in 2017 (see Section 4.4.2). In addition, action 51 states that a Communities Integration Fund (CIF) will be established to support actions by local communities throughout Ireland to promote the integration of migrants and refugees. The CIF was established in 2017 (see Section 4.4.1).

During consultations for the current study, the Immigrant Council of Ireland (ICI) and Crosscare both stressed that local needs should be responded to, at local level. ${ }^{165} \mathrm{ICl}$ also stressed the importance of local integration strategies complementing the national integration strategy $(\mathrm{ICl}, 2018) \cdot{ }^{166}$ Gilmartin and Dagg (2018) observed that migrant integration services in urban areas tend to be provided by migrant NGOs, while services at regional level are more likely to be provided by local authorities, local development companies and ETBs, with a smaller number of NGOs involved.

\subsection{LOCAL AUTHORITY INVOLVEMENT}

Implementation of relevant actions under the national migrant integration strategy occurs at local government level with oversight by OPMI. There are 31 local authorities in Ireland, each with its own local strategy or strategies for managing various issues at local level, including migrant integration and social cohesion. Under the national strategy, local authorities are required to update their migrant integration strategies between 2017 and 2020. In July 2018, a total of 21 local authorities had a local migrant integration strategy in place or had had one at some point in the past; however, only three were found to have a current migrant integration strategy $(\mathrm{ICl}, 2018)$.

OPMI noted that collating information on migrant integration activities has proven difficult as only one member of the Migrant Integration Strategy Monitoring and Coordination Committee represents all 31 local authorities. OPMI also noted that, at present, it does not make a direct input regarding integration matters when it comes to local authorities' budget planning processes. ${ }^{167}$ OPMI hosted a one-day

Comments received from OPMI, May 2019.

Interview with $\mathrm{ICl}$, May 2018.

Interview with ICl, May 2018.

Interview with OPMI, May 2018. 
conference for local authorities in November 2018, which was attended by 28 local authorities, as well as the Local Government Management Authority (LGMA). ${ }^{168}$

The establishment of a migrant integration forum within each local authority and an integration network in Dublin City Council were reported as being underway at time of writing (actions 53 and 54 respectively). Waterford City Council and Waterford County Council, in partnership with Waterford Local Community and Development Committee and partner agencies, launched its migrant integration forum in 2019. Dublin City Council is in the process of bringing approximately 55 migrant organisations together to form a linkage group called Dublin's Migrant Network. ${ }^{169}$

\subsection{SOCIAL INCLUSION ACTIVITIES}

The Irish Local Development Network represents 49 local development companies that deliver a range of programmes such as: the Rural Development Programme LEADER, managed by Department of Rural and Community Development; the Rural Social Scheme; Tús, the Local Employment Service; Jobs Clubs; the Rural Recreation Programme; the Walks Scheme; the Back to Work Enterprise Allowance; and social enterprise programmes across rural and urban Ireland. ${ }^{170}$

SICAP 2018-2022 is funded by the Irish government through the DRCD and cofunded by the European Social Fund (ESF) under the Programme for Employability, Inclusion and Learning (PEIL 2014-2020). In it, new communities are identified as a target group. ${ }^{171}$ The three core goals of SICAP are to strengthen local communities, promote lifelong learning and help people to become more job ready. SICAP commenced on 1 April 2015 and by 2016 it had supported 3,056 local community groups and 47,511 individuals on a one-to-one basis (Whelan et al., 2019).

SICAP is managed by 33 local community development committees, with support from local authorities, and is delivered by programme implementers. The implementers work with marginalised communities and service providers to improve people's lives. This may include upskilling, CV training, personal development courses, interview preparation or finding work placement programmes. ${ }^{172}$ The nationality and ethnic background of participants are

\footnotetext{
168 'Supporting integrated communities: Local authorities and migrant integration' in Athlone (November 2018). Comments received from OPMI, May 2019. Comments received from OPMI, May 2019. Irish Local Development Network, 'Irish Local Development Network', http://ildn.ie/. Pobal, 'The Social Inclusion and Community Activation Programme 2018-2022', www. pobal.ie. Ibid.
} 
identified on the SICAP database, which allows the outcomes of these groups to be monitored (Fahey et al., 2019).

While these are mainstream programmes that migrants may access, some programmes in areas where there are larger migrant populations have a greater focus on migrants. Galway City Partnership for example established the 'Galway Migrant Service', which provides employment and English language supports. ${ }^{173}$

Crosscare noted that there is no reporting link between the national migrant integration strategy and SICAP. They added that, generally, community initiatives that are responding to the needs of migrants identified in the community itself are not linked directly to national programmes or to the migrant integration strategy. ${ }^{174}$

\subsection{NATIONAL FUNDING TARGETING MIGRANT INTEGRATION}

In recent years there has been an increase in integration-related activities and an increase in public funds available for integration activities specifically for refugees and other migrants (Arnold et. al., 2018).

Funding through national OPMI-administered programmes include:

- The National Funding to Promote the Integration of Immigrants;

- The Communities Integration Fund (CIF); and

- $\quad$ EU funds.

The Government uses two sources of EU funding to support migrant integration programmes: the EU's Asylum, Migration and Integration Fund (AMIF) and ESF Programme for Employability, Inclusion and Learning (PEIL) 2014-2020. ${ }^{175}$

Each year between 2016 and 2019, OPMI issued calls for funding applications and allocated funds to community and private sector organisations under these funding programmes. The projects that were selected to receive state funding, as well as the description of the funding calls, indicate integration priority at national level and correlate with certain actions in the migrant integration strategy. ${ }^{176}$

Murphy et al. (2017) note that despite a clear policy intent that integration policies and measures should be mainstreamed into the work of government departments, a recent survey of integration policies in the public sector found no clear evidence

Galway City Partnership, 'Galway Migrant Service', available at http://gcp.ie. Interview with Crosscare, April 2018.

OPMI, 'Funding', available at http://www.integration.ie/en/isec/pages/opmi\%20funding. In November 2017, €485,226 was awarded through the Dormant Accounts Fund to seven projects nationwide to support the labour-market integration of female refugees and the female family members of refugees. This funding falls outside the scope of the current study. 
that this has happened. Gilmartin and Dagg (2018) state that this is also the case in relation to funding programmes targeting migrant integration. They noted that, of the total funds allocated under integration schemes they reviewed, ${ }^{177}$ just under 60 per cent was earmarked for non-governmental organisations, with around 21 per cent allocated to local development companies, and almost six per cent to two private companies involved in labour activation programmes. No additional funds were allocated to government departments for integration measures, and around 0.3 per cent of funds were allocated to local authorities. Departments cannot apply for each other's funding, save for Dormant Accounts Funds. ${ }^{178}$

\subsubsection{Community Integration Fund (CIF)}

As stated above, CIF was established in 2017 along with the launch of the current migrant integration strategy. In February 2017, it was announced that approximately $€ 500,000$ would be available under CIF. ${ }^{179} \mathrm{~A}$ similar sum was made available in 2018 and in 2019. ${ }^{180}$ Grants from $€ 5,000$ are awarded; 131 projects were funded in 2017 and 115 in 2018. ${ }^{181}$ The Minister of State for Justice at the Department of Justice and Equality with special responsibility for equality, immigration and integration, Mr. David Stanton T.D., stated that the purpose of CIF is to bring people together, particularly people who perhaps would not ordinarily have the opportunity to interact or to get to know one another. He noted that interaction is a vital part of the integration process. ${ }^{182}$ The fund is nationally funded, but implemented and operated at local or community level. Among organisations in receipt of funding include those that provide 'soft skills' support measures that are not necessarily targeted the labour market (one example would be Fáilte Isteach). ${ }^{183}$ In 2017, two of the 131 projects focused specifically on employment (OPMI, 2018b).

Based on findings from the 2017 funding programme, OPMI specified a number of special themes under which projects were particularly desirable in 2018. These themes included activities aimed at challenging racism, activities focusing on migrant women, elderly and lesbian, gay, bisexual and transgender (LGBT) migrants and activities aimed at addressing barriers to migrant participation in sports clubs. Projects offering advice on seeking employment or employment opportunities through training and sponsorship were among a further ten general

Note that these figures include all integration funding (not just labour market and including measures specific to beneficiaries of international protection). Comments received from OPMI, May 2019.

179 DJE, 'Minister Stanton announces National Funding to Promote the Integration of Immigrants', press release, 23 February 2017, available at http://www.justice.ie/en/JELR/Pages/PR17000066. In 2019, $€ 526,000$ was made available: the additional $€ 26,000$ was provided by the OPW for integration-throughart projects. OPMI, 'CIF2017 - List of projects awarded grants'; OPMI, 'CIF2018 - List of projects awarded grants', both available at http://www.integration.ie/. 
themes identified. ${ }^{184}$ This theme featured again in the launch of the 2019 CIF (DJE, 2019a).

The beneficiary organisations are responsible for implementing the projects. They must report progress to OPMI. ${ }^{185}$ In addition, beneficiary organisations and projects must submit a final report two months before the end of the project period. While the evaluation of the $2017 \mathrm{CIF}$ found that the majority of projects funded were based in and around urban areas (Dublin City, Galway City and Cork City), all 26 counties in the Republic of Ireland were represented among the 131 successful applications (OPMI, 2018b). The 2018 list of projects funded shows a similar geographic spread. The 2017 evaluation report, undertaken by OPMI, forms part of the implementation of action 5 (evaluation and monitoring of funding initiatives) of the migrant integration strategy. ${ }^{186}$ The CIF itself is linked to action 6 (related to the provision of funding by OPMI) and action 51 (development of CIF). An implementation report of CIF 2018 is expected to be published during 2019. ${ }^{187}$

\subsubsection{National Funding to Promote the Integration of Immigrants}

The funding scheme National Funding to Promote the Integration of Immigrants was introduced in May 2017. It is resourced by the OPMI at the Department of Justice and Equality and complements CIF. ${ }^{188}$ Projects running for up to 36 months were invited to apply. Some 15 projects were granted a total of $€ 1,900,000$ (Department of Justice and Equality, 2017c). While the funding programme is national, the projects are implemented locally. Irish, EU nationals and non-EU nationals all fall within the scope of the funding programme.

The aims of the 2017 funding call included:

- increasing mutual understanding between host communities and immigrants;

- combating racism and xenophobia;

- facilitating language acquisition aimed at enabling immigrants to access employment and/or to integrate into their local communities;

- $\quad$ promoting the integration into Irish society of vulnerable or socially excluded immigrants;

\footnotetext{
184 OPMI, 'Communities Integration Fund 2018', available at http://integration.ie/en/ISEC/Pages/Communities_Integartion_Fund_2018_Main. OPMI, 'Report templates for grant recipients', available at http://www.integration.ie/en/isec/pages/report_templates. Comments received from OPMI, April 2019.

See

http://www.integration.ie/en/ISEC/Communities\%20Integration\%20Fund\%202018\%20Guidance.pdf/Files/Commu nities\%20Integration\%20Fund\%202018\%20Guidance.pdf. 
- providing training to public and private sector organisations on equality and integration;

- $\quad$ providing information and support for immigrants in regard to access to services;

- $\quad$ providing information and support for immigrants in regard to immigration and citizenship;

- promoting integration in schools;

- $\quad$ promoting integration in the youth sector;

- $\quad$ promoting integration in the workplace; and

- $\quad$ promoting the involvement of immigrants in sport, volunteering and cultural activities.

Six of the 15 projects target the labour market integration of migrants. Two are discussed in Box 4.1.

BOX 4.1 PROJECTS FUNDED UNDER NATIONAL FUNDING TO PROMOTE THE INTEGRATION OF IMMIGRANTS

\section{Migrant Teacher Project, Marino Institute of Education}

The Marino Institute of Education's Migrant Teacher Project aims to increase the participation of immigrant, internationally educated teachers in the Irish primary and post-primary education sectors. ${ }^{189}$ The project provides information, advice and training through its Bridging Programme to teachers who have qualified outside of Ireland, to help them seek employment in Irish primary and post-primary schools. The Migrant Teacher Project reported that a lack of social capital, especially in the form of contacts in schools, emerged strongly as an issue in the needs analysis research with teachers and with school principals. For this reason, a 'school experience' element was incorporated into the Bridging Programme. A total of 140 applications were received for 40 places on the Bridging Programme. In April 2019, the Migrant Teacher Project reported that nearly 20 per cent of Bridging Programme participants had taken up employment. ${ }^{190}$

\section{Employment and Integration Service, Mendicity Institution}

The Mendicity Institution's Employment and Integration service facilitates access to employment for homeless, vulnerable and socially excluded migrants living in Dublin. The service provides a personalised job-seeking support plan through workshops and equips participants with practical job-seeking skills. The service also runs through Polish, Romanian and Russian to facilitate non-English speakers. ${ }^{191}$ The teaching profession in Ireland is predominantly Irish, particularly at primary level, with 95 per cent of trainee teachers reported to be 'White Irish' (Donnelly, 2017).

190 Consultation with the Migrant Teacher Project, April 2019.

191 Mendicity Institution, 'Employment and integration', available at http://www.mendicity.org/projects/employmentproject/.
} 
The projects described in Box 4.1 are managed and implemented by the lead beneficiary organisation with funding via OPMI. They range from 12 to 36 months in duration. Project outcomes and results will be collated at the end of the programme. ${ }^{192}$ Beneficiary organisations are required to report on progress to OPMI. ${ }^{193}$ The projects reflect the objectives set out in actions 39 and 40 of the migrant integration strategy.

\subsubsection{Integration projects funded through the ESF (PEIL)}

Funding was also announced for allocation from the ESF PEIL 2014-2020 (DJE, 2017b). The ESF is the EU's primary financial instrument for investing in people and aims to combat unemployment and invest in education, skills and employment support to make the workforce and companies better equipped to face new challenges and prevent people from losing touch with the labour market. The PEIL is the operational programme through which ESF funding is implemented in Ireland (DJE, 2017b). In line with priorities set out in Article 3 of the ESF Regulation (EU Regulation No 1304/2013), the key areas chosen for investment in Ireland through the PEIL were: activation of the unemployed; promoting social inclusion and combating labour market discrimination; investing in education and training to upand re-skill the labour force; and youth employment (Government of Ireland, 2018). The funding was made available through the Department of Justice and Equality under two calls in $\mathbf{2 0 1 6}$ for projects of up to four years: PEIL integration and employment of migrants; and PEIL gender equality. Under the PEIL integration and employment of migrants, a total of $€ 3.3$ million funding was available. The gender equality measure was not targeted specifically at migrants, but some projects selected had a migrant focus.

EEA nationals who are resident in Ireland and non-EEA nationals with permission to enter employment in Ireland are eligible to participate in the programmes. The projects target disadvantaged groups. Non-EU nationals can access the programmes voluntarily and free of charge through (self)-referrals, ${ }^{194}$ outreach, ${ }^{195}$ or as existing service users. ${ }^{196}$

\section{PEIL integration and employment of migrants projects}

The employment target for Ireland under the Europe 2020 Strategy $^{197}$ and the Partnership Agreement on the European structural and investment funds 2014-

Comments received from OPMI, May 2019.

OPMI, 'Report templates for grant recipients', available at

http://www.integration.ie/en/isec/pages/report_templates.

EPIC, JUMP, MAP and Seetec, 'Welcome to work'. (See Box 3.1, Box 4.2 and Box 4.4.)

Kilkenny Migrants 'New Start' Programme (see Box 4.2).

$\mathrm{MRCl}$, Building better futures - Building social enterprise with migrant women entrepreneurs.

The Europe 2020 Strategy is a ten-year strategy proposed by the European Commission in 2010 for the advancement of the economy of the European Union. 
$2020,{ }^{198}$ is to raise employment to $69-71$ per cent for women and men aged 2064 years, including through better integration of migrants (DPER, 2014). The funding call for integration and employment of migrants aims at migrants who are experiencing barriers to participation and employment because of language difficulties, lack of training or social exclusion (Department of Justice and Equality, 2016a).

Five projects are underway across Ireland delivered by NGOs, locally based community groups and others. All five projects seek to introduce migrants to the labour market by enhancing their language skills, information technology (IT) competencies, application skills and work experience. The projects involve close cooperation between the community, public sector and private sector (see Box 4.2). 


\section{BITCI: Employment for People from Immigrant Communities (EPIC)}

EPIC is run by Business in the Community Ireland (BITCI) and funded under the ESF for the period 2017-2021 and under the National Programme. See Box 3.1, Chapter 3 for a discussion of the programme.

\section{Kilkenny Leader Partnership: Kilkenny Migrants NewStart Programme}

The Kilkenny Migrants NewStart Programme is led by the Kilkenny LEADER Partnership, a non-profit community-led local development organisation, and is implemented by a coalition of groups including the Kilkenny Integration Forum, Kilkenny County Council, Kilkenny and Carlow Education and Training Board, St. Canices Community Action Network and Kilkenny Empowerment Initiative for African Women. The programme aims to progress up to 150 migrants into employment, self-employment, social enterprise or further education. It focuses on providing an individual learning plan for each participant, increasing English language and IT competency, and improving job-readiness. ${ }^{199}$

\section{Cultúr: JUMP}

The JUMP project delivered by Cultúr is a support and training programme developed to enhance knowledge and skills of migrants in County Meath, in order to facilitate improved access to employment and training supports. It offers English language courses and assessment, career planning workshops, work placements, and coaching and mentoring. ${ }^{200}$

\section{New Communities Partnership: Migrant Access Programme (MAP)}

MAP, delivered by New Communities Partnership (NCP), offers four-week intensive training courses, focusing on upskilling to improve access to the labour market; for example, English proficiency, computer and CV training and interview skills. MAP also offers one-day information sessions to groups of migrants nationwide to introduce them to the Irish labour market. ${ }^{201}$ MAP was established when NCP observed that mainstream services available to migrants were not tailored to the needs of migrants. To date, typically three out of ten participants have found employment during the four-week training programme. NCP identifies confidence building among participants as one of the main benefits of the programme. ${ }^{202}$

\section{Seetec: Welcome to Work}

Welcome to Work operated by Seetec offers a 13-week programme of labour market integrations supports (see Box 4.4).

\footnotetext{
199 Kilkenny Leader Partnership, 'NewStart', http://www.cklp.ie/migrant-support/.

200 Cultúr, 'Jump programme', available at http://cultur.ie/jump-programme-3/.

201 Interview with NCP, May 2018.

202 Interview with NCP, May 2018.
} 


\section{PEIL gender equality}

The PEIL gender equality funding call sought to fund projects aimed at women returning to the workforce and women's entrepreneurship in line with objectives set out in the government's Action plan for jobs 2016, the 2014 National policy statement on entrepreneurship and the DEASP's Pathways to work 2016-2020. The budget was approximately $€ 5.2$ million for 18 projects. The funding call launched in 2016 , and the projects run for three years.

One project, entitled Building Better Futures - Building Social Enterprise with Migrant Women Entrepreneurs, specifically targets migrant women and women from an immigrant background who have previous business experience and have a start-up idea (Box 3.2).

In addition, Southside Partnership received funding through the ESF for a project to assist women to access the labour market (Department of Justice and Equality, 2017b).

A mid-term evaluation of the national ESF PEIL, including the Employment and Gender Equality funding streams, was published in December 2018 (Government of Ireland, 2018). Beneficiary organisations must provide information to the EU Funds Unit, which collects reporting information on behalf of OPMI to ensure allocated funds are used for their intended purpose. Financial information has to be provided quarterly, operational information twice yearly, and audited and expenditure accounts annually (Department of Justice and Equality, 2016a).

\subsubsection{EU Asylum, Migration and Integration Fund}

In September 2016 it was announced that EU funding would be made available from AMIF for migrant integration projects. Some €4.5 million was allocated under the EU AMIF to 'promote the integration of non-EU migrants and to combat discrimination and racism'. Non-EU nationals, including refugees and asylum seekers (the latter in some cases), may participate in the projects.

Under this AMIF call, 20 projects were selected and the funds were awarded in 2016. The project implementation period is 2017-2020. Organisations had to provide 25 per cent match funding (Department of Justice and Equality, 2016c).

The funded projects focus on:

- fostering integration through sport and through drama (1);

- $\quad$ providing holistic rehabilitation to victims of torture (1);

- $\quad$ providing integration interventions/activities in the school setting (2);

- $\quad$ providing information and training (capacity building) to service users and stakeholders on rights and entitlements (9); 
- $\quad$ providing skills and training to migrants to help them facilitate access to the labour market and the housing market (3);

- $\quad$ providing legal and case work support to refugees and asylum seekers (1);

- $\quad$ providing parenting, school readiness and other support to new community families (1); and

- $\quad$ political participation (1).

Some 13 out of 20 projects that received funding focused on general integration support measures. ${ }^{203}$ Of these, one included access to work experience, ${ }^{204}$ one aimed to increase participation in mainstream youth work provision, ${ }^{205}$ and one focused on supporting persons in low wage and un-regulated sectors (discussed in Box 4.3). ${ }^{206}$ AMIF

\section{The MUKISA Capacity Building Programme}

This programme promotes integration and capacity-building of the migrant community in counties Carlow, Kilkenny, Waterford and Wexford. Some 40 non-EU nationals can engage in the programme, which includes English language training, QQI accredited training and work experience. The ownership of this project was transferred from Edmund Rice to Waterford Area Partnership in 2018. ${ }^{207}$

\section{Advancing Rights and Building Capacity of Low-waged Non-EU Nationals}

This Migrant Rights Centre Ireland ( $\mathrm{MRCl}$ ) project targets non-EU nationals most at risk of poverty, exclusion and discrimination, who work in low-waged and un-regulated sectors. The programme will support 2,200 non-EU nationals per year to access rights and entitlements and take up mainstream services.

The beneficiaries of the project funds are responsible for the implementation of the projects, which began in 2017 and are ongoing. The EU Funds Unit monitors implementation on behalf of OPMI to ensure allocated funds are used for their intended purpose. All beneficiaries provide financial information quarterly,

Clare Immigrant Support Centre Ltd; Crosscare; Doras Luimní; Edmund Rice; Galway City Partnership; Irish Refugee Council; Jesuit Refugee Service; Killarney Immigrant Support Centre; Laois Partnership Company; Mary Immaculate College; MRCI; NASC; South Dublin County Partnership; and South West Mayo Development Company. 'MUKISA Capacity Building Programme. been discontinued at the request of the implementing organisation. Comments received from OPMI, May 2019. $\mathrm{MRCl}$ 'Advancing rights and building capacity of low waged TCNs'.

207 Comments received from OPMI, May 2019. 
operational information twice yearly, as well as audited and expenditure accounts annually (DJE, 2016d).

\subsubsection{Future and continuation of funding administered by OPMI}

While the increase in focus on promoting labour market integration in national funding in recent years was noted by stakeholders, ${ }^{208} \mathrm{BITCl}$ observed that the amount of funding made available to labour market integration is small relative to the need. $\mathrm{BITCl}$ expressed the view that most funding is allocated to programmes implemented in the Dublin area, which means that it cannot be meeting the need for supports throughout the country. ${ }^{209}$

In April 2019, the DJE launched a further call for proposals under the EU Asylum, Migration and Integration Fund (AMIF). Some $€ 4.5$ million has been made available to projects, including those designed to assist third country nationals and eligible asylum seekers to overcome barriers to employment. A further $€ 5.5$ million has been made available under the ESF gender equality project, Women Returning to the Workforce and Women's Entrepreneurship. Projects applying for funding must have a minimum budget of $€ 200,000$ (Department of Justice and Equality, 2019b).

The migrant integration strategy itself runs to 2020 and the responsible Ministers have regularly recommended that it be viewed as a 'living document' ${ }^{210}$ However, it is not yet known whether a follow-on strategy will be developed.

Again it is important to note the crucial role that funding from other mainstream government departments plays in supporting labour market integration in Ireland. Examples include funding through the FET sector, through SICAP and other national and regional programmes.

At the EU level, the European Migration Network (EMN) (2019) points to a lack of institutionalised funding, as well as significant political changes in certain Member States, as threats to the sustainability of measures and their long-term success.

On 2 May 2018, the European Commission issued a proposal for a new multiannual financial framework for 2021-2027, which includes proposals for the allocation of further funding available to Member States through the AMIF and ESF (European Commission, 2018). The proposal is currently undergoing negotiations in the European Parliament and Council of the EU. 


\subsection{PRIVATE SECTOR}

Across the EU, private sector measures aim at integrating migrant workers into the workplace, focusing mainly on training and qualifications, counselling and enhancing intercultural relations in the workplace (EMN, 2019). EMN (2019) further notes that the private sector can add value to national labour market integration strategies, including by meeting gaps wherever public measures fall short; for example, due to a lack of or insecure public funding. Research on local implementation of migrant integration programmes in European cities conducted by the Organisation for Economic Co-operation and Development (OECD) in 2018 noted that the private sector is not sufficiently involved in migrant inclusion initiatives. The OECD stated it is essential to create more opportunities for migrants to interact with the private sector and to sensitise the local business community to encourage work opportunities for migrants (OECD, 2018b).

In Ireland to date, the private sector has been more involved in debates on labour and skills shortages than on integration. Employers input regularly to DBEI reviews of the critical skills occupation list and ineligible list of occupations, as well as to sectoral research studies produced by the Expert Group on Future Skills Needs (Gusciute at al., 2015). BITCI noted that much discussion in the private sector is focused on attracting migrant workers to address labour shortages, with less emphasis placed on the labour market integration and upskilling of those already living in Ireland. However, BITCl observed that, in the context of economic growth and skills shortages in Ireland, businesses are willing to get more involved in labour market integration initiatives. ${ }^{211}$

In Ireland, the national migrant integration strategy pulls all government departments together, whereas private sector involvement in the implementation of the migrant integration strategy is limited. ${ }^{212} \mathrm{~A}$ representative from the Irish Congress of Trade Unions (ICTU) participates in the Migrant Integration Strategy Monitoring and Coordination Committee. While IBEC took part in consultations on the development of the strategy, it has not, to date, participated in this committee. ${ }^{213}$ OPMI is involved in the implementation of Towards responsible business: The second national plan on corporate social responsibility (CSR) (DBEI, 2017)..$^{214}$

OPMI also uses its position on the Corporate Social Responsibility Stakeholder Forum to promote migrant integration in the workforce as a sustainable development goal under the workplace dimension of the above national plan on 
CSR. ${ }^{215}$ In the May 2018 minutes of the Migrant Integration Strategy and Coordination Committee, it was noted that actions 56 and $57^{216}$ are being progressed through this national action plan on CSR, and through funded projects such as the EPIC programme (OPMI, 2018a).

OPMI commented that there is a need for 'collective responsibility' - for the corporate sector to become more engaged - because migration inflows will continue and Ireland will continue to take its responsibility seriously in the area of international protection. ${ }^{217}$

There are nevertheless some examples of private sector businesses that provide labour market integration support services to migrants in Ireland, with public funding. Examples include EPIC (see Box 3.1) and Welcome to Work by Seetec (see Box 4.4). ETB Skills for Work programme and MRCl's migrant women's entrepreneur project are also examples of private sector involvement in public and community sector projects (see Box 3.2).

\section{BOX 4.4 WELCOME TO WORK}

The Welcome to Work programme is operated by Seetec and funded under the ESF PEIL (see Box 4.2). ${ }^{218}$ It provides a 13-week programme aimed at EU and non-EU migrants in Castlebar, Galway and Monaghan. The project will engage 507 migrants, support 410 participants on the programme and move 187 into employment or training. The project will target the most disadvantaged migrant groups to maximise impact (Department of Justice and Equality, 2017b).

In the programme, applicants attend for assessment and create a personalised action plan. It includes group and one-on-one online support sessions to build skills and integration; skills addressed include English language, employability skills, volunteering, training, job search and broking support. Beneficiaries can continue to access Seetec centres and inemployment supports up to 12 months after completing the programme.

\subsubsection{Diversity charter}

$\mathrm{ICl}$ and NCP identified discrimination and stigma as challenges to the integration of migrants into the labour market in Ireland. ${ }^{219}$ As discussed in Section 2.4, research also indicates that migrants may experience more discrimination than Irish

\footnotetext{
215 Interview with OPMI, May 2018.

216 'Encourage businesses to focus on integration' and 'Invite speakers to present on integration to existing business sector relationships/engagements' respectively.

217 Interview with OPMI, May 2018.

218

Seetec is an international company registered in the UK with subsidiaries in Ireland. It operates in the employment and recruitment sector and is a medium-sized company (50-249 employees). 
nationals (McGinnity et al., 2018c.; Kingston et al., 2012; Kingston et al., 2015). The Diversity Charter Ireland was launched on 5 October 2012 by 11 organisations that have agreed to work together to promote greater diversity among the workforce. They represent the broader business community, including IBEC, the group that represents Irish business. As of February 2019, there are 58 signatories to Diversity Charter Ireland, ${ }^{220}$ covering more than 130,000 employees in Ireland. ${ }^{221}$ The signing of this charter is a voluntary commitment by these organisations to effective diversity management, prevention of discrimination and promotion of equality with respect to all their stakeholders and the environment in which they operate. ${ }^{222,223}$ The initiative forms part of the EU Platform of Diversity Charters, which was established in 2010 by the European Commission to share experience and good practices. Diversity charters have also been launched and signed by organisations in 22 other EU Member States to date. ${ }^{224}$

The migrant integration strategy refers to Diversity Charter Ireland in its introduction as a reflection of how many businesses recognise the importance of managing workplace diversity successfully (DJE, 2017a). Furthermore, OPMI is responsible under the strategy for encouraging businesses to focus on integration (action 56). In pursuit of this action, OPMI provides funding to support the work of Diversity Charter Ireland to leverage what has already been done and to encourage more companies to join the charter and spread best practice. ${ }^{225}$

Comments received from OPMI, May 2019.

See https://www.equalitystrategies.com/.

Diversity Charter, 'Irish charter', available at http://www. diversity-charter.com/diversity-charter-irelandcharter.php. Interview with $\mathrm{BITCI}$, April 2018.

Austria, Belgium, the Czech Republic, Croatia, Denmark, Estonia, Finland, France, Germany, Hungary, Italy, Latvia, Lithuania, Luxembourg, the Netherlands, Poland, Portugal, Romania, Slovakia, Slovenia, Spain and Sweden. See European Commission, 'Diversity charters by EU country', available at https://ec.europa.eu/info/policies/justiceand-fundamental-rights/combatting-discrimination/tackling-discrimination/diversity-management/diversitycharters-eu-country_en. Interview with OPMI, May 2018. Comments received from OPMI, May 2019. 


\section{CHAPTER 5}

\section{Conclusion}

This study focuses on The migrant integration strategy: A blueprint for the future as the key policy statement on migrant integration in Ireland. This strategy provides a framework for government action, which aims to ensure the active participation of migrants in Irish communities, workplaces and politics. However, it is acknowledged that migrant integration policy does not stop with the migrant integration strategy. Ireland's mainstreamed approach to integration means that service-providing departments and agencies also play a key role. In addition, other important programmes and initiatives for community development at local level in Ireland impact significantly. The rules governing which non-EEA nationals can work in Ireland and under what conditions also form an important backdrop to any measures to support labour market integration. The monitoring of labour market integration is important in tracking the outcomes of migrant groups, and how well their needs are being served by mainstream services and measures.

The focus of the migrant integration strategy is on ensuring the equitable provision of public services within the mainstreamed system of migrant integration, with the Office for the Promotion of Migrant Integration (OPMI) leading and co-ordinating across departments. This cross-departmental approach was highlighted by OPMI as important aspect of the process, one that can be challenging to implement. Ensuring engagement with, and even awareness of, the strategy within other departments is not always easy. ${ }^{226}$ Murphy et al. (2017) showed that while many public bodies actively engage with general inclusion policies, such as those related to concepts such as equality and diversity, integration policy is generally underdeveloped in the public sector in Ireland, with few public bodies having a policy or other document that explicitly mentions migrant integration.

Recent years have seen an increase in integration activities, including in relation to labour market integration, that are available to migrants in Ireland. An increase has also been observed in funds administered by OPMI, and made available under the Community Integration Fund (CIF), the National Funding to Promote the Integration of Immigrants, The European Social Fund's (ESF) Programme for Employability, Inclusion and Learning (PEIL), the Asylum, Migration and Integration Fund (AMIF) and the Dormant Accounts Fund. Ireland is not unique in this regard; The European Migration Network (EMN) (2019) shows that in many EU Member States existing labour market integration policies have been updated and new policies developed, partly in response to increased migration flows. This study 
highlights the diversity of labour market integration projects funded in recent years.

The migrant integration strategy stresses the stability offered by employment, and the important opportunities employment offers, in terms of engaging with others in the community. Of the 76 actions in the strategy assigned to government departments and agencies, NGOs, political parties and other organisations, ten relate specifically to labour market integration. This is significant as a growing body of research points to the problems faced by some migrants in the Irish labour market (McGinnity et al., 2018c; MRCI, 2015a; Kingston et al., 2012; Kingston et al., 2015; McGinnity et al., 2018c; O'Connell, 2018; Gusciute et al., 2016; DEASP, 2018). One action has been marked complete, five are considered to be on track and four have 'minor problems or delays'.

OPMI observed that the publication of the migrant integration strategy is evidence of the political priority accorded to migrant integration, including labour market integration. ${ }^{227}$ Crosscare, Enterprise and Training Boards Ireland (ETBI), Immigrant Council of Ireland (ICI), Migrants Rights Centre Ireland (MRCI), the New Communities Partnership (NCP) and OPMI all observed that the availability of funding for the provision of further education and training and labour market integration projects indicates that labour market integration is a political priority. ${ }^{228}$ However, NGOs expressed the view that labour market integration of non-EU nationals specifically is nevertheless not afforded sufficient priority, as reflected in the lack of debate or focus on integration at a political level. They also expressed the view that attracting labour to meet skills demands currently takes higher priority.

While NGOs consulted broadly welcomed the migrant integration strategy, ${ }^{229}$ Crosscare noted that it is up to each government department and agency to decide the extent to which they engage with the strategy, and that this poses a challenge for implementation. ${ }^{230}$ The broad nature of the actions, as well as the absence of clear targets, was also highlighted by stakeholders as an implementation challenge. ${ }^{231}$ The Migrant Integration Strategy Monitoring and Coordination Committee, which includes representatives of government departments, public bodies, local authorities, and NGOs, provides crucial oversight, while delivery is the responsibility of the action 'owners'. An Integration Data Working Group was also established and their work has recently been informed by a mapping study on the availability of quantitative data relevant to the study of migrant integration in 
Ireland (Fahey et al., 2019). There has also been progress made in recent years on monitoring the integration of migrants in Irish society (McGinnity et al., 2018a).

In principle, migrant integration takes place at local level, within communities (Council of the European Union, 2004; European Commission, 2011; OECD, 2018b). Implementation of relevant actions assigned to local authorities occurs at local government level with oversight by OPMI. However, collating information on activities has proven difficult as only one member of the Migrant Integration Strategy Monitoring and Coordination Committee represents all 31 local authorities. At present, OPMI does not make a direct input regarding integration matters when it comes to local authorities' budget planning processes. ${ }^{232}$ Crosscare noted that there is no reporting link between the strategy and the Social Inclusion Community Activation Programme (SICAP) 2018-2022; neither is there reference to local partnerships in the strategy. Gilmartin and Dagg (2018) note that the bulk of funding available has gone to NGOs and local development companies, but that funding tends to be short term, and thus continuity and stability of services is lacking. In addition, Gilmartin and Dagg (2018) note that services for migrants are often based on status rather than specific needs and that there is considerable scope for improvement.

Private sector involvement in the design and implementation of the migrant integration strategy is limited. OPMI noted the need for 'collective responsibility' in this regard and for the corporate sector to become more engaged regarding the labour market integration of migrants. Some stakeholders commented that in Ireland to date, the private sector has been more involved in debates on labour and skills shortages than on integration.

An important issue for both local and national programmes in the area of labour market integration, however they are funded, is their coverage, in terms of the number of people who benefit from the measure. Equally important is how effective they are at achieving their aims. Some programmes may be very effective in integrating participants, for example non-EEA nationals, into the labour market but target a very small number of participants. Conversely, some may be very large in terms of budget throughput, but less effective. Thorough evaluations of programmes are thus crucial and it is important that any learning from evaluations is incorporated fully into future policy measures.

Labour market integration is about more than the migrant integration strategy. Labour migration policy and regulations that govern access to the labour market for non-EU nationals are important in this context. A lack of clarity around entitlement to work will inhibit labour market integration, as both jobseekers and 
employers may not know who has permission to work. Policy focus on upskilling and activating the resident population, seen for example in Future jobs Ireland 2019, is perhaps even more important than the competition for talent from abroad. The issue of how non-EEA migrants' needs are being served by more general labour market programmes in Ireland is also relevant. The analysis conducted by the Department of Employment Affairs and Social Protection (DEASP) on the characteristics and outcomes of jobseekers of African nationality is a good example of this (DEASP, 2018). Further research could usefully investigate the extent to which non-EEA migrants are being integrated into the Irish labour market through mainstreamed policy provision. 


\section{REFERENCES}

Arnold, S. and E. Quinn (2016a). Resettlement of refugees and private sponsorship in Ireland, European Migration Network, Research Series No. 55, Dublin: Economic and Social Research Institute.

Arnold, S., and E. Quinn (2016b). Family reunification of Non-EU nationals in Ireland, European Migration Network, Research Series No. 62, Dublin: Economic and Social Research Institute.

Arnold, S., C. Ryan and E. Quinn (2018). Ireland's response to recent trends in international protection applications, Research Series No. 72, Dublin: Economic and Social Research Institute.

Barrett, A., A. Bergin, E. Kelly and S. McGuiness (2016). 'Ireland's recession and the immigrant/native earnings gap', in M. Kahanec and K.F. Zimmermann (eds.) Labor migration, EU enlargement and the Great Recession, Berlin: Springer.

Barrett, A. and D. Duffy (2008). 'Are Ireland's immigrants integrating into its labour market?', International Migration Review, Vol. 42, No. 3, pp. 597-619.

Barrett, A., F. McGinnity, and E. Quinn (2017). Monitoring report on integration 2016, Dublin: Economic and Social Research Institute.

Barrett, A., S. McGuinness and M. O'Brien (2012). 'The immigrant earnings disadvantage across the earnings and skills distributions: The case of immigrants from the EU's New Member States', British Journal of Industrial Relations, Vol. 50, No. 3.

Business in the Community (n.d.). Back to work business supporting work placements, Dublin: Business in the Community, available at https://www.bitc.ie/wpcontent/uploads/2015/09/Final-BITC-Back-to-Work-Placement2.pdf.

Central Statistics Office (CSO) (2016a). Census of population 2016 - Profile 11 employment, occupations and industry, available at https://www.cso.ie/en/releasesandpublications/ep/p-cp11eoi/cp11eoi/lfnmfl/.

Council of the European Union (2004). 2,618th meeting: Justice and home affairs, press release, 14615/04 (presse 321), available at https://www.consilium.europa.eu/ueDocs/cms_Data/docs/pressData/en/jha/827 45.pdf.

Crosscare (2018). Do you speak English? A Study on access to interpreter services in public social welfare offices in Ireland, Dublin: Crosscare.

Department of Business, Enterprise and Innovation (2018). Review of economic migration policy: Report of the Inter-Departmental Group, available at https://dbei.gov.ie/en/Publications/Publication-files/Review-of-EconomicMigration-Policy.pdf.

Department of Business, Enterprise and Innovation (DBEI) (2019). Future jobs Ireland: Preparing now for tomorrow's economy, available at https://dbei.gov.ie/en/Publications/Publication-files/Future-Jobs-Ireland2019.pdf. 
Department of Business, Enterprise and Innovation (DBEI) (2017). Towards responsible business: Ireland's national plan on corporate social responsibility 2017-2020, available at

https://dbei.gov.ie/en/Publications/Publication-files/Towards-ResponsibleBusiness-Ireland\%E2\%80\%99s-National-Plan-CSR-2017-2020.pdf.

Department of Education and Skills (DES) and SOLAS (2014). Further education and training strategy 2014-2019, Dublin: SOLAS, available at https://www.education.ie/en/Publications/Policy-Reports/Further-Educationand-Training-Strategy-2014-2019.pdf.

Department of Education and Skills (DES) and SOLAS (2017). Further education and training expenditure: Strategic pilot initiative report, Dublin: SOLAS, available at http://www.solas.ie/SolasPdfLibrary/Evaluating\%20Further\%20Education\%20and \%20Training\%20Expenditure\%20-

\%20Strategic\%20Pilot\%20Initiative\%20Report.pdf.

Department of Employment Affairs and Social Protection (DEASP) (2018). Department of Employment Affairs and Social Protection analysis under action 42 of the Migrant Integration Strategy: Characteristics and outcomes of jobseekers of African nationality, Dublin: Department of Employment Affairs and Social Protection.

Department of Justice and Equality (DJE) (2016a). European Social Fund Programme for Employability, Inclusion and Learning (PEIL) 2014-2020: Integration and employment of migrants - Call for proposals 2016, information and guidance for applicants, available at

http://eufunding.justice.ie/en/EUFunding/Information\%20and\%20Guidance\%20E SF\%20PEIL\%20IntEmplMigrants.pdf/Files/Information\%20and\%20Guidance\%20E SF\%20PEIL\%20IntEmpIMigrants.pdf.

Department of Justice and Equality (DJE) (2016b). European Social Fund Programme for Employability, Inclusion and Learning (PEIL) 2014-2020: Gender equality call for proposals 2016, information and guidance for applicants, Dublin: Department of Justice and Equality.

Department of Justice and Equality (DJE) (2016c). Asylum Migration and Integration Fund Ireland, call for proposals 2016: Reception, integration and capacity building projects funded 2017-2019, Dublin: Department of Justice and Equality.

Department of Justice and Equality (DJE) (2016d). Asylum Migration and Integration Fund Ireland, call for proposals 2016: Information and guidance for applicants, available at

http://eufunding.justice.ie/en/EUFunding/AMIF\%20Information\%20and\%20Guid ance.pdf/Files/AMIF\%20Information\%20and\%20Guidance.pdf.

Department of Justice and Equality (DJE) (2017a). The migrant integration strategy: $A$ blueprint for the future, Dublin: Department of Justice and Equality.

Department of Justice and Equality (DJE) (2017b). European Social Fund Programme for Employability, Inclusion and Learning (PEIL) 2014-2020, funded projects: PEIL integration and employment of migrants and PEIL gender equality, Dublin: Department of Justice and Equality. 
Department of Justice and Equality (DJE) (2017c). 'Projects funded under National Funding to Promote the Integration of Immigrants', available at

http://www.integration.ie/en/ISEC/NFP2017\%20-

\%20List\%20of\%20Funded\%20projects.pdf/Files/NFP2017\%20-

\%20List\%20of\%20Funded\%20projects.pdf.

Department of Justice and Equality (DJE) (2019a). 'Minister Stanton launches 2019 Communities Integration Fund,' media release, Dublin: Department of Justice and Equality.

Department of Justice and Equality (DJE) (2019b). 'Minister Stanton launches €10m open call for proposals for projects under European funding,' Media release, Dublin: Department of Justice and Equality.

Department of Justice, Equality and Law Reform (1999). Integration: A two way process, Dublin: Department of Justice, Equality and Law Reform.

Department of Justice and Equality (DJE) and Department of Business, Enterprise and Innovation (DBEI) (2019). 'Ministers Flanagan and Humphreys announce change to immigration arrangements for spouses and partners of critical skills employment permit holders,' Media release, Dublin: Department of Justice and Equality.

Department of Public Expenditure and Reform (DPER) (2014). Partnership agreement on the European structural and investment funds 2014-2020, Dublin: Department of Public Expenditure and Reform.

Department of Social Protection (DPER) (2016). Updated national action plan for social inclusion 2015-2017, Dublin: Department of Social Protection.

Donnelly, K. (2017). 'Putting out a fáilte for migrant teachers', Irish Independent, 14 December 2017, available at

https://www.independent.ie/irish-news/education/putting-out-a-filte-for-

migrant-teachers-36402752.html.

European Commission (2011). European agenda for the integration of third-country nationals, $\operatorname{COM(2011)~} 455$ final, available at

https://eur-lex.europa.eu/legal-

content/EN/TXT/PDF/?uri=CELEX:52011DC0455\&from=EN.

European Commission (2016). Action plan on the integration of third-country nationals, $\operatorname{COM}(2016) 377$ final, available at

https://ec.europa.eu/home-affairs/sites/homeaffairs/files/what-we-

do/policies/european-agenda-migration/proposal-implementation-

package/docs/20160607/communication_action_plan_integration_third-

country_nationals_en.pdf.

European Commission (2018). A modern budget for a union that protects, empowers and defends: The multiannual financial framework for 2021-2027, COM(2018) 321 final, available at

https://ec.europa.eu/commission/sites/beta-political/files/communicationmodern-budget-may2018_en.pdf.

European Migration Network (2018). EMN glossary version 3.0, Brussels: European Migration Network. 
European Migration Network (2019). Labour market integration of third-country nationals in EU Member States - Synthesis report, Brussels: European Migration Network.

Eurobarometer (2018). Special Eurobarometer 469 report: Integration of immigrants in the European Union, Brussels: European Union.

Fahey, É., F. McGinnity and E. Quinn (2019). Data for monitoring integration: Gaps, challenges and opportunities, Dublin: Economic and Social Research Institute and the Department of Justice and Equality.

Fanning, B. (2015). 'Immigration, the Celtic Tiger and the economic crisis', Irish Studies Review, Volume 42, No. 1.

Gilmartin and Dagg (2018). Immigrant integration and settlement services in Ireland, project report, Irish Research Council, available at:

http://mural.maynoothuniversity.ie/10114/1/Immigrant\%20Integration\%20Final \%20Report\%202018\%20\%28002\%29.pdf.

Glynn, I. (2014). An overview of Ireland's integration policies, INTERACT RR 2014/10, Robert Schuman Centre for Advanced Studies, San Domenico di Fiesole (FI): European University Institute.

Government of Ireland (2018). Programme for employability, inclusion and learning 20142020 mid-term evaluation: Final report, available at https://www.esf.ie/en/Information-Centre/Evaluation/EvaluationReports/PEIL\%20MTE\%20and\%20YEl\%20Evaluation.pdf.

Gusciute, E., E. Quinn and A. Barrett (2015). 'Determining labour and skills shortages and the need for labour migration in Ireland,' European Migration Network, Dublin: Economic and Social Research Institute.

Gusciute, E., S. Arnold and E. Quinn (2016). Integration of beneficiaries of international protection into the labour market: Policies and practices in Ireland, European Migration Network, Dublin: Economic and Social Research Institute.

Huddleston, T., O. Bilgili, A-L. Joki and Z. Vankova (2015). Migrant Integration Policy Index 2015, Barcelona/Brussels: CIDOB and MPG.

Immigrant Council of Ireland (ICI) (2018). Keeping it local: Discussion document and proposed actions for local authorities on developing local migrant integration strategies, available at

https://www.immigrantcouncil.ie/sites/default/files/2018-

07/Keeping\%20it\%20local\%20Report\%20WEB\%20version.pdf.

INIS (2016). Policy document on non-EEA family reunification, Dublin: Department of Justice and Equality.

Kett, M. (2018). English language provision and language assessment for low-skilled and unemployed migrants: Recommendations for good practice at NFQ levels 1-3 in ETBs, Dublin: ETBI and SOLAS.

Kingston, G., F. McGinnity and P. O'Connell (2015). 'Discrimination in the labour market: Nationality, ethnicity and the recession', Work, Employment and Society Vol. 29, No. 2. 
Kingston, G., P. O'Connell and E. Kelly (2012). Ethnicity and nationality in the irish labour market: Evidence from the QNHS Equality Module 2010, Dublin: The Equality Authority and the Economic and Social Research Institute.

Laois-Offaly ETB (2017). Evaluation self-evaluation report for Laois and Offaly ETB, Portlaoise: Laois-Offaly ETB.

McGinnity, F., E. Quinn, P. O'Connell and N. Donnelly (2011). Annual monitoring report on integration 2010, Dublin: Economic and Social Research Institute and the Integration Centre.

McGinnity, F., E. Quinn, G. Kingston and P. O'Connell (2012). Annual monitoring report on integration 2011, Dublin: Economic and Social Research Institute and the Integration Centre.

McGinnity, F., E, Quinn., G. Kingston and P. O'Connell (2013). Annual monitoring report on integration 2012, Dublin: Economic and Social Research Institute and the Integration Centre.

McGinnity, F., E. Quinn, G. Kingston and P. O'Connell (2014). Annual monitoring report on integration 2013, Dublin: Economic and Social Research Institute and the Integration Centre.

McGinnity, F., É. Fahey, E. Quinn, S. Arnold, B. Maître and P. J. O'Connell, (2018a). Annual monitoring report on integration 2018, Dublin: Economic and Social Research Institute and the Department of Justice and Equality.

McGinnity, F., R. Grotti, H. Russell and E. Fahey (2018b). Attitudes to diversity in Ireland, Dublin: Economic and Social Research Institute and the Irish Human Rights and Equality Commission.

McGinnity, F., R. Grotti, S. Groarke and S. Coughlan (2018c). Ethnicity and nationality in the Irish labour market, Dublin: Economic and Social Research Institute and the Irish Human Rights and Equality Commission.

McGuinness, S., A. Bergin, E. Kelly, S. McCoy, E. Smyth, D. Watson and A. Whelan (2018). Evaluation of PLC programme provision, Dublin: Economic and Social Research Institute.

Migrant Rights Centre Ireland (MRCI) (2015a). All work and low pay: The experience of migrants working in Ireland, Dublin: Migrant Rights Centre Ireland.

MRCI (2015b). Workers on the move: Past lessons and future perspectives on Ireland's labour migration, Dublin: Migrant Rights Centre Ireland.

Murphy, C., L. Caulfield and M. Gilmartin (2017). Developing integration policy in the public sector: A human rights approach, Maynooth: National University of Ireland Maynooth.

O'Connell, P.J. (2018). 'Why are so few Africans at work in Ireland? Immigration policy and labour market disadvantage', Geary WP2018/16, Dublin: UCD Geary Institute for Public Policy. 
Office for the Promotion of Migrant Integration (OPMI) (2018a). 'Minutes of the 4th meeting of the Migrant Integration Strategy Monitoring and Co-ordination Committee,' available at http://www.integration.ie/en/ISEC/MISMCC\%20-\%2004\%200ct\%202017\%20\%20Minutes.pdf/Files/MISMCC\%20-\%2004\%200ct\%202017\%20$\% 20$ Minutes.pdf.

Office of the Promotion of Migrant Integration (OPMI) (2018b). Communities Integration Fund 2017: Implementation report, Dublin: Department of Justice and Equality.

Organisation of Economic Co-operation and Development (OECD) (2017). How's life in Ireland? available at https://www.oecd.org/ireland/Better-Life-Initiative-country-note-Ireland.pdf.

Organisation of Economic Co-operation and Development (OECD) (2018a). Economic survey Ireland, available at https://www.oecd.org/eco/surveys/Ireland-2018-OECD-economic-surveyoverview.pdf.

Organisation of Economic Co-operation and Development (OECD) (2018b). Working together for local integration of migrants and refugees, available at https://www.oecd-ilibrary.org/docserver/9789264085350en. pdf?expires=1558974001\&id=id\&accname=guest\&checksum=0D4C20CD9CCE 332E3AF6D05B6997E19A.

Pollak, S. (2018). 'Clarity needed around Stamp 3 holders' right to apply for jobs, says campaign', The Irish Times, 11 September 2018, available at https://www.irishtimes.com/news/social-affairs/clarity-needed-around-stamp-3holders-right-to-apply-for-jobs-says-campaign-1.3625853.

Pollak, S. (2019). 'Partners of critical skills permit holders to be given "direct access" to Irish labour market', The Irish Times, 6 March 2019, available at https://www.irishtimes.com/news/social-affairs/partners-of-critical-skills-permitholders-to-be-given-direct-access-to-irish-labour-market-1.3816182.

Ruhs, M. and Quinn, E. (2009). 'Ireland: From rapid immigration to recession', Migration Information Source, available at https://www.migrationpolicy.org/article/ireland-rapid-immigration-recession/.

SOLAS (2014). Further education and training strategy 2014-2019, Dublin: SOLAS.

SOLAS (2016). The 2016 further education and training (FET) services plan, Dublin: SOLAS.

SOLAS (2018). The 2018 further education and training (FET) services plan, Dublin: SOLAS.

The Carers Association, Migrant Rights Centre Ireland (MRCI) and Services Industrial Professional and Technical Union (SIPTU) (2015). Employment guidelines for the home care sector: The workers' perspective, Dublin: $\mathrm{MRCl}$, the Carers Association and SIPTU.

The Integration Centre (2012). Roadmap to integration 2012, Dublin: The Integration Centre.

UNHCR (2013). Towards a new beginning: Refugee integration in Ireland, Dublin: UNHCR. 
Voitchovsky, S. (2014). 'Occupational downgrading and wages of new Member States immigrants to Ireland', International Migration Review, Vol. 48, No. 2, pp. 500537.

Whelan, A., S. McGuinness and J. Delaney (2019). Valuing community development through the Social Inclusion Programme (SICAP) 2015-2017: Towards a framework for evaluation, Dublin: Economic and Social Research Institute. 



\section{ANNEX 1}

\section{Employment integration indicators}

\section{ZARAGOZA INDICATORS: EMPLOYMENT CORE INDICATORS}

Employment rate: The proportion of working adults in the working age population.

Unemployment rate: The proportion of unemployed adults in the labour force, which is the sum of the numbers of persons employed plus unemployed.

Activity rate: The proportion of working age adults in the population who are in the labour force, which is the sum of the numbers of persons employed and unemployed.

\section{FURTHER RECOMMENDED AREAS AND INDICATORS (WHERE DATA EXIST)}

Share of employees who are overqualified for their jobs.

Self-employment.

Source: European Commission, 'Declaration of the European Ministerial Conference on Integration (Zaragoza, 15 \& 16 April 2010)', available at https://ec.europa.eu/migrantintegration/librarydoc/declaration-of-the-european-ministerial-conference-on-integrationzaragoza-15-16-april-2010. 


\section{ANNEX 2}

\section{Overview of main trends in Europe}

The number of non-EU citizens residing in the EU on 1 January 2018 was 22.3 million, representing 4.4 per cent of the EU28 population. ${ }^{233}$ The ad-hoc module on migration of the Labour Market Survey in 2014, which includes 16 Member States (not including Ireland) shows that 76 per cent of non-EU nationals who migrated for work to the EU had no job at the time of migrating (EMN, 2019).

Table A.1 shows that the total number of valid residence permits held by non-EU nationals for family reasons was just under 7.8 million in 2017. ${ }^{234}$ This represents an increase of 6.5 per cent between 2014 and 2017 (from 7,296,959 to 7,769,999). Residence permits issued for family reasons remained constant from 2015 to 2017. Residence permits for family reasons accounted for 38 per cent of the total $20,340,585$ residence permits issued to non-EU nationals in 2017. The total number of valid residence permits issued for the purpose of work increased by six per cent between 2014 to 2017, to reach 3.2 million. The proportion of residence permits issued for the purposes of work was 16 per cent of the total permits issued in 2017. Residence permits issued to students and beneficiaries of international protection represented 13 per cent of the total permits issued in 2017. However, students and beneficiaries of international protection are outside the scope of the study.

TABLE A.1 NON-EEA RESIDENCE PERMITS VALID IN EU, 2014-2017

\begin{tabular}{|l|r|r|r|r|}
\hline Residence permit reason & \multicolumn{2}{|l}{2014} & 2015 & 2017 \\
\hline Family & $7,296,959$ & $7,433,148$ & $7,432,043$ & $7,769,999$ \\
\hline Other & $6,408,188$ & $6,557,060$ & $6,488,315$ & $6,659,008$ \\
\hline Remunerated activities & $3,044,862$ & $3,109,337$ & $3,113,916$ & $3,217,477$ \\
\hline Education & $1,116,467$ & $1,160,945$ & $1,150,328$ & $1,212,460$ \\
\hline International protection & 622,952 & 745,798 & $1,147,710$ & $1,481,641$ \\
\hline Total & $18,489,428$ & $19,006,288$ & $19,332,312$ & $19,525,751$ \\
\hline
\end{tabular}

Source: Eurostat [migr_resvalid]

Eurostat [migr_pop1ctz].

Valid residence permit means any authorisation valid for at least three months issued by the authorities of a Member State allowing a TCN to stay legally on its territory. Eurostat [migr_resvalid]. 

EMN Ireland,

Economic and Social

Research Institute,

Whitaker Square,

Sir John Rogerson's Quay,

Dublin 2, Ireland

Telephone +353 18632000

Email emn.ireland@esri.ie

Web www.emn.ie / www.esri.ie

Twitter @EMNIreland

ISBN: 978-0-7070-0494-5 